\title{
Vida oficial da RAG
}

\author{
A ACademia na actualidade \\ Crónica da Academia (2020) \\ NecrolóxicAs: \\ Xosé Luís Franco Grande (1936 - 2020) / Ramón Lorenzo \\ No Relumbrar da túa memoranza (A Luz Pozo Garza) / \\ / Salvador García-Bodaño \\ Luz Pozo Garza (1922 - 2020). Aeternitate / \\ / Olivia Rodríguez González
}





\section{A ACADEMIA NA ACTUALIDADE (ANO 2020)}

Dende o 28 de marzo de 2017, a Comisión Executiva da Real Academia Galega está formada polos seguintes membros:

- Presidente: D. Víctor Fernández Freixanes

- Secretario: D. Xosé Henrique Monteagudo Romero

- Vicesecretario: D. Andrés Torres Queiruga

- Arquiveira-Bibliotecaria: D. ${ }^{a}$ Fina Casalderrey

- Tesoureira: D. ${ }^{a}$ Marilar Aleixandre

Relación dos actuais membros numerarios:

1. Excmo. Sr. D. Andrés Torres Queiruga. Ingreso: 20 de xuño de 1980.

2. Excmo. Sr. D. Manuel González González. Ingreso: 7 de febreiro de 1992.

3. Excmo. Sr. D. Salvador García-Bodaño Zunzunegui. Ingreso: 25 de novembro de 1992.

4. Excmo. Sr. D. Xesús Alonso Montero. Ingreso: 30 de outubro de 1993.

5. Excmo. Sr. D. Xesús Ferro Ruibal. Ingreso: 4 de maio de 1996.

6. Excma. Sra. D.․ Luz Pozo Garza. Ingreso: 29 de novembro de 1996. Faleceu o 20 de abril de 2020.

7. Excmo. Sr. D. Xosé Ramón Barreiro Fernández. Ingreso: 14 de febreiro de 1997. Faleceu o 17 de marzo de 2021.

8. Excmo. Sr. D. Xosé Luís Franco Grande. Ingreso: 3 de xullo de 1998. Faleceu o 31 de marzo de 2020.

9. Excmo. Sr. D. Antón Santamarina Fernández. Ingreso: 24 de outubro de 1998.

10. Excmo. Sr. D. Ramón Lorenzo Vázquez. Ingreso: 7 de maio de 1999.

11. Excmo. Sr. D. Francisco Fernández Rei. Ingreso: 25 de setembro de 1999.

12. Excmo. Sr. D. Francisco Díaz-Fierros Viqueira. Ingreso: 28 de setembro de 2002.

13. Excma. Sra. D. a Rosario Álvarez Blanco. Ingreso: 6 de xuño de 2003.

14. Excmo. Sr. D. Víctor Fernández Freixanes. Ingreso: 27 de febreiro de 2004.

15. Excmo. Sr. D. Xosé Luís Axeitos Agrelo. Ingreso: 30 de outubro de 2004.

16. Excmo. Sr. D. Euloxio Rodríguez Ruibal. Ingreso: 24 de marzo de 2006.

17. Excmo. Sr. D. Darío Xohán Cabana Yanes. Ingreso: 22 de abril de 2006.

18. Excmo. Sr. D. Ramón Villares Paz. Ingreso: 24 de novembro de 2006.

19. Excma. Sra. D. - Margarita Ledo Andión. Ingreso: 7 de febreiro de 2009. 
20. Excmo. Sr. D. Manuel Rivas Barrós. Ingreso: 12 de decembro de 2009.

21. Excmo. Sr. D. Bernardino Graña Villar. Ingreso: 12 de xuño de 2010.

22. Excmo. Sr. D. Xosé Henrique Monteagudo Romero. Ingreso: 25 de febreiro de 2012.

23. Excmo. Sr. D. Xosé Luís Regueira Fernández. Ingreso: 2 de xuño de 2012.

24. Excmo. Sr. D. Pegerto Saavedra Fernández. Ingreso: 14 de setembro de 2013.

25. Excma. Sra. D. - Fina Casalderrey Fraga. Ingreso: 22 de novembro de 2013.

26. Excma. Sra. D. a Marilar Aleixandre. Ingreso: 14 de xaneiro de 2017.

27. Excma. Sra. D. ․ M. Xesús Pato Díaz. Ingreso: 23 de setembro de 2017.

28. Excma. Sra. D. a Ana Romaní. Ingreso: 6 de abril de 2019.

29. Ilma. Sra. D. ${ }^{a}$ María Dolores Sánchez Palomino. Electa: 17 de novembro de 2020.

30. Ilma. Sra. D. a Ana Isabel Boullón Agrelo. Electa: 22 de decembro de 2020.

Relación dos actuais membros de honra:

1. Excmo. Sr. D. John Rutherford. Ingreso: 4 de outubro de 2008.

2. Excmo. Sr. D. Carlos Alberto Zubillaga Barrera.

Ingreso: 21 de abril de 2012.

3. Excmo. Sr. D. Arcadio López-Casanova. Ingreso: 9 de novembro de 2013.

4. Excma. Sra. D. a Nélida Piñon. Ingreso: 27 de setembro de 2014.

5. Excmo. Sr. D. Basilio Losada Castro. Ingreso: 3 de outubro de 2015.

6. Excma. Sra. D. - Marina Mayoral. Ingreso: 2 de decembro de 2017.

7. Excma. Sra. D. a María Rosa Lojo. Electa: 21 de decembro de 2019.

Relación dos actuais membros correspondentes por orde de ingreso:

1. Ilmo. Sr. D. José Luis Varela Iglesias. Ingreso: 26 de marzo de 1950.

2. Ilmo. Sr. D. José Ignacio Carro Otero. Ingreso: 22 de outubro de 1967.

3. Ilmo. Sr. D. Xosé López Calo. Ingreso: 22 de outubro de 1967. Faleceu o 10 de maio de 2020.

4. Ilmo. Sr. D. Xosé Manuel González Reboredo. Ingreso: 30 de xaneiro de 1972.

5. Ilmo. Sr. D. Xosé Carlos Rivas González. Ingreso: 15 de maio de 1977.

6. Ilmo. Sr. D. Francisco Xavier Carro Rosende. Ingreso: 17 de novembro de 2001.

7. Ilmo. Sr. D. Fernando López-Acuña López. Ingreso: 17 de novembro de 2001.

8. Ilmo. Sr. D. Ivo Castro. Ingreso: 9 de febreiro de 2002.

9. Ilmo. Sr. D. Dieter Kremer. Ingreso: 9 de febreiro de 2002. 
10. Ilma. Sra. D. a Teresa Barro Muñoz-Ortiz. Ingreso: 22 de xuño de 2002.

11. Ilmo. Sr. D. Xosé María Lema Suárez. Ingreso: 22 de xuño de 2002.

12. Ilmo. Sr. D. Xulio Ríos. Ingreso: 22 de xuño de 2002.

13. Ilmo. Sr. D. Luís Daviña Facal. Ingreso: 28 de setembro de 2002.

14. Ilmo. Sr. D. Johannes Kabatek. Ingreso: 28 de setembro de 2002.

15. Ilmo. Sr. D. Xoán Babarro González. Ingreso: 14 de decembro de 2002.

16. Ilmo. Sr. D. Xoán Bernárdez Vilar. Ingreso: 22 de febreiro de 2003.

17. Ilmo. Sr. D. Francisco Calo Lourido. Ingreso: 22 de febreiro de 2003.

18. Ilmo. Sr. D. Augusto Pérez Alberti. Ingreso: 7 de febreiro de 2004.

19. Ilmo. Sr. D. Xosé Xove Ferreiro. Ingreso: 7 de febreiro de 2004.

20. Ilmo. Sr. D. Modesto Aníbal Rodríguez Neira.

Ingreso: 27 de marzo de 2004.

21. Ilma. Sra. D.ํㅗa María Dolores Sánchez Palomino.

Ingreso: 27 de marzo de 2004.

22. Ilmo. Sr. D. Francisco Antonio Cidrás Escáneo.

Ingreso: 27 de marzo de 2004.

23. Ilmo. Sr. D. Ernesto Xosé González Seoane.

Ingreso: 27 de marzo de 2004.

24. Ilmo. Sr. D. Domingo Frades Gaspar. Ingreso: 27 de marzo de 2004.

25. Ilmo. Sr. D. Felipe Lubián Lubián. Ingreso: 9 de outubro de 2004.

26. Ilmo. Sr. D. Héctor Manuel Silveiro Fernández.

Ingreso: 9 de outubro de 2004.

27. Ilmo. Sr. D. Carlos Xesús Varela Aenlle. Ingreso: 9 de outubro de 2004.

28. Ilmo. Sr. D. Manuel Caamaño Suárez. Ingreso: 18 de decembro de 2004.

29. Ilmo. Sr. D. Jorge Arbeleche. Ingreso: 20 de setembro de 2005.

30. Ilmo. Sr. D. Craig Patterson. Ingreso: 13 de xaneiro de 2007.

31. Ilmo. Sr. D. Luís Manuel García Mañá. Ingreso: 28 de abril de 2007.

32. Ilmo. Sr. D. Farruco Sesto Novas. Ingreso: 15 de xaneiro de 2011.

33. Ilma. Sra. D. a Débora Campos Vázquez. Ingreso: 25 de marzo de 2011.

34. Ilma. Sra. D. a Ana Isabel Boullón Agrelo.

Ingreso: 21 de xaneiro de 2012.

35. Ilmo. Sr. D. Xosé Henrique Costas González.

Ingreso: 21 de xaneiro de 2012.

36. Ilmo. Sr. D. Gonzalo Navaza Blanco. Ingreso: 21 de xaneiro de 2012.

37. Ilmo. Sr. D. Antón Palacio Sánchez. Ingreso: 21 de xaneiro de 2012.

38. Ilmo. Sr. D. Francisco Cerviño González. Ingreso: 30 de marzo de 2012.

39. Ilma. Sra. D. - Alba Nogueira López. Ingreso: 30 de marzo de 2012.

40. Ilmo. Sr. D. Xavier Vence Deza. Ingreso: 22 de xuño de 2012.

41. Ilma. Sra. D. a Olivia Rodríguez González. Ingreso: 22 de xuño de 2012. 
42. Ilmo. Sr. D. Fernando Ramallo Fernández. Ingreso: 22 de xuño de 2012.

43. Ilmo. Sr. D. José Manuel González Herrán. Ingreso: 22 de xuño de 2012.

44. Ilma. Sra. D. ${ }^{a}$ Luz Méndez Fernández. Ingreso: 22 de xuño de 2012.

45. Ilma. Sra. D. - María Goretti Sanmartín Rei. Ingreso: 22 de xuño de 2012.

46. Ilmo. Sr. D. Xosé Antón Fraga Vázquez. Ingreso: 18 de xaneiro de 2013.

47. Ilmo. Sr. D. Clodio González Pérez. Ingreso: 5 de novembro de 2016.

48. Ilmo. Sr. D. Jorge Mira Pérez. Ingreso: 16 de decembro de 2016.

49. Ilmo. Sr. D. Carlos Xabier Rodríguez Brandeiro.

Ingreso: 16 de decembro de 2016.

50. Ilmo. Sr. D. Takekazu Asaka. Ingreso: 17 de xuño de 2017.

51. Ilmo. Sr. D. Marcos Bagno. Ingreso: 17 de xuño de 2017.

52. Ilma. Sra. D. a Olga Castro. Ingreso: 17 de xuño de 2017.

53. Ilma. Sra. D. - Helena González Fernández. Ingreso: 17 de xuño de 2017.

54. Ilma. Sra. D. - Kirsty Hooper. Ingreso: 17 de xuño de 2017.

55. Ilma. Sra. D. ${ }^{a}$ Helena Villar Janeiro. Ingreso: 17 de xuño de 2017.

56. Ilma. Sra. D. ${ }^{a}$ Helena Zernova. Ingreso: 17 de xuño de 2017.

57. Ilma. Sra. D. ${ }^{a}$ Carme Pazos Balado. Ingreso: 17 de marzo de 2018.

58. Ilmo. Sr. D. Afonso Vázquez Monxardín.

Ingreso: 26 de outubro de 2018.

59. Ilma. Sra. D.․ㅡ Mercedes Queixas Zas. Ingreso: 14 de decembro de 2018.

60. Ilmo. Sr. D. Xavier Senín Fernández. Ingreso: 3 de outubro de 2020. 


\section{CRÓNICA DA ACADEMIA (ANO 2020)}

\section{Xuntas Académicas}

O Pleno da Real Academia Galega reuniuse en Xunta ordinaria e extraordinaria, durante o ano 2020, nas seguintes datas:

Xuntas ordinarias:

- 3 de xullo de 2020.

- 3 de outubro de 2020 (reunión virtual e presencial).

- 17 de novembro de 2020 (reunión virtual e presencial).

- 22 de decembro de 2020 (reunión virtual e presencial).

Xuntas extraordinarias:

- 12 de decembro de 2020.

Día das Letras Galegas dedicado a Ricardo Carballo Calero.

A Comisión Executiva da Real Academia Galega reuniuse nas seguintes datas:

- 10 de xaneiro

- 28 de xaneiro

-18 de febreiro

- 2 de marzo

- 13 de marzo

- 25 de marzo (reunión virtual)

- 8 de abril (reunión virtual)

- 23 de abril (reunión virtual)

- 12 de maio

- 15 de maio

- 11 de xuño
- 18 de xuño

- 3 de xullo

- 29 de xullo

- 7 de setembro

- 23 de setembro

- 8 de outubro

- 29 de outubro

- 23 de novembro (reunión virtual)

- 2 de decembro (reunión virtual)

- 17 de decembro (reunión virtual) 


\section{Día DAS LETRAS GALEGAS DE 2020}

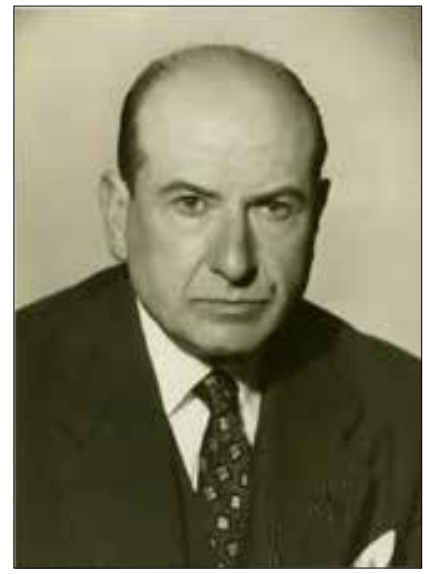

Foto: Real Academia Galega

$\mathrm{Na}$ xuntanza ordinaria celebrada polo plenario da Real Academia Galega o día 22 de xuño de 2019 tomouse o acordo de que o Día das Letras Galegas de 2020 estaría dedicado a Ricardo Carballo Calero (Ferrol, 1910-Santiago de Compostela, 1990), cadrando cos 110 anos do seu nacemento e os 30 anos do seu pasamento. O profesor ferrolán, unha das figuras máis relevantes da cultura galega da segunda metade do século XX, desenvolveu unha traxectoria vital fondamente vencellada á historia do galeguismo dese século: foi na mocidade membro do Seminario de Estudos Galegos e colaborador da revista Nós, participou na redacción do Estatuto de Autonomía de 1936 e, xa no exilio interior, implicouse activamente nas estratexias de recuperación do idioma propio. Membro da Real Academia Galega, destacou tanto no ámbito da creación literaria como no da crítica e no da investigación filolóxica, converténdose en 1972 no primeiro catedrático de Lingua e Literatura Galegas.

Ricardo Carballo Calero medrou en Ferrol, rematou o bacharelato na Coruña e en 1926 marchou estudar Dereito e Filosofía a Santiago de Compostela, onde mantivo unha intensa actividade intelectual e política: entrou axiña en contacto co galeguismo artellado arredor do Seminario de Estudos Galegos - do que chegou a ser secretario xeral- e cultivou un estreita relación con Vicente Risco, Castelao, Ramón Otero Pedrayo e outros mestres da Xeración Nós. Nesta etapa redactou un manifesto sobre a galeguización da universidade (subscrito, entre outros, por Álvaro Cunqueiro ou Francisco Fernández del Riego) e participou na fundación do Partido Galeguista e no proceso de redacción do Estatuto de Autonomía para Galicia. Dos anos de mocidade son ademais as súas primeira obras literarias, os poemarios Vieiros (1931), o seu primeiro libro en galego, e O silenzo axionllado (1934).

A guerra civil estopou cando preparaba en Madrid as oposicións á cátedra de bacharelato, despois de acadar unha praza de funcionario no seu concello natal. Loitou no bando republicano, como miliciano primeiro e logo como tenente, e en 1939 foi detido e condenado a prisión. Dous anos despois foi posto en liberdade, pero prohibíuselle ocupar cargos públicos. Empezaría daquela unha etapa dedicada ao ensino privado que o levaría en 1950 a fixar a súa residencia en Lugo para 
dirixir o Colexio Fingoi, mentres restablecía relacións co galeguismo que non se exiliara. Ese mesmo ano fundábase a Editorial Galaxia, un proxecto co que colaborou activamente. Participou na primeira xeira da Colección Grial e foi membro do consello de redacción e constante colaborador da revista Grial desde a súa saída en 1963 ata 1989, pouco antes do seu pasamento.

No ámbito académico, en 1954 doutorouse en Madrid coa tese Aportaciones a la literatura gallega contemporánea. En 1958 ingresou como membro de número da Real Academia Galega, co discurso titulado Contribución ao estudo das fontes literarias de Rosalía, e máis adiante sería o redactor, xunto a Ramón Piñeiro, das primeiras normas ortográficas e morfolóxicas aprobadas por esta institución (1970-1971). En 1965 incorporouse como profesor interino á Universidade de Santiago de Compostela, da que foi o primeiro docente das materias de lingua e literatura galegas, que se acababan de introducir como optativas nos programas universitarios; e en 1972 converteuse no primeiro catedrático de Lingua e Literatura Galegas, posto do que se xubilou no ano 1980. Durante as últimas décadas da súa vida mantivo unha intensa actividade como articulista e colaborador en prensa, residindo de xeito permanente en Santiago de Compostela, onde faleceu en 1990. O seu labor foi recoñecido nestes anos dentro e fóra de Galicia. En 1981 foi nomeado membro da Academia das Ciencias de Lisboa e en 1984 recibiu a Medalla Castelao.

\section{DA CREACIÓN AO ESTUDO DA LITERATURA}

A obra de creación literaria de Carballo Calero transita os diversos xéneros canónicos e suma uns vinte libros. Como narrador publicou A xente da Barreira (1951) - premio Bibliófilos Gallegos e primeira novela en galego da posguerra, cunha historia centrada nunha saga fidalga do rural-, Scórpio (1987) -na que retrata a xeración dos vencidos na guerra civil e considerada en certos aspectos autobiográfica- e relatos curtos. Tamén cultivou a poesía, con títulos como Vieiros (1931), O silenzo axionllado (1934), Anxo de terra (1950), Poemas pendurados dun cabelo (1952), Salterio de Fingoy (1961) e os volumes antolóxicos Pretérito imperfeito (1980), Cantigas de amigo e outros poemas (1986) ou Reticências... (1990). Igualmente, fixo achegas á literatura galega como dramaturgo: Catro pezas: A sombra de Orfeo, Farsa das zocas, A arbre, Auto do prisioneiro (1971) ou Teatro completo (1982).

Na súa extensa produción destacan os seus estudos sobre a literatura, que con frecuencia atravesan as fronteiras entre os xéneros didáctico e ensaístico. Entre as súas importantísimas contribucións á historiografía literaria sobresae a erudita Historia da literatura contemporánea galega (1963), o esforzo de sistematización da nosa literatura máis ambicioso e significativo da segunda metade do século XX. 
Nos estudos que publicou na década de 1970 sobre diversos autores salientan os que lle dedicou a Rosalía de Castro, coa edición da súa poesía e análises da lingua e da obra literaria da poeta (Estudios rosalianos, 1979). Unha parte deses traballos están recollidos en colectáneas como Libros e autores galegos (2 volumes, 1979 e 1982), Estudos e ensaios sobre literatura galega (1989) e Escritos sobre Castelao (1989). Foi tamén moi relevante a súa actividade como conferenciante e articulista, incluso nas páxinas da prensa diaria, arredor de asuntos de índole filolóxica ou cultural. Recolleitas de traballos deste tipo atópanse nos volumes misceláneos Umha voz na Galiza. Artigos de Jornal (1933-1989) (1992) e Ricardo Carvalho Calero: a ciencia ao servizo da nación (2010).

Carballo Calero é ademais autor da Gramática elemental del gallego común (Galaxia, 1966), manual de referencia para as primeiras xeracións de estudantes de lingua galega e que atinxiu unha gran difusión, ata chegar ás sete edicións. A de 1979, a derradeira, ten cambios importantes na ortografía e en escollas léxicas e, sobre todo, morfolóxicas a raíz do cambio na concepción de Carballo sobre o que debería ser o galego culto, xa que desde mediados da década dos 70 pasou a defender a adopción dunha ortografía próxima á portuguesa para o galego e a aceptación do portugués como referencia fundamental do galego estándar. A partir desas datas empeza a asinar como Ricardo Carvalho Calero. Os seus traballos lingüísticos e a exposición e propostas de orientación reintegracionista foron recollidos en volumes como Problemas da Língua Galega (Lisboa, 1981), Da fala e da escrita (1983) e Do galego e da Galiza (1990). 


\section{SESIÓN ACADÉMICA}

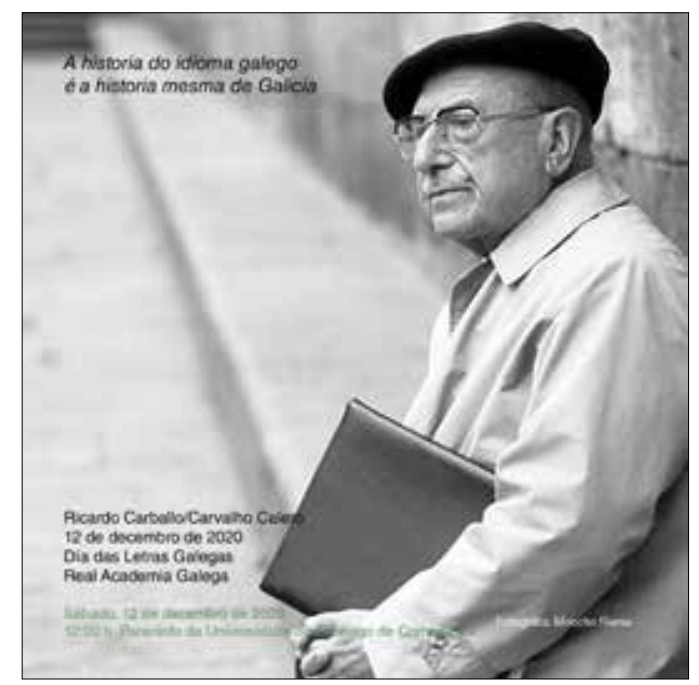

A Real Academia Galega desenvolveu o acto central do Día das Letras Galegas no Paraninfo da Universidade de Santiago de Compostela o día 12 de decembro de 2020.

A entrada en vigor do estado de alarma provocado pola pandemia da covid-19 o 5 de marzo obrigou a Real Academia Galega a tomar unha decisión inédita nos cincuenta e sete anos de historia da celebración do Día das Letras Galegas: no mes de abril acordouse trasladar a celebración do domingo 17 de maio ao sábado 31 de outubro, xusto un día despois do 110 aniversario do nacemento do homenaxeado, mantendo a localización pensada nun principio, o teatro Jofre de Ferrol. Non obstante, o empeoramento da situación sanitaria no mes de outubro fixo que, dous días antes da nova data prevista, se reconsiderase a situación do acto, emprazando a súa celebración no salón de actos da rúa Tabernas e ofrecendo a retransmisión deste a través da Rede. Finalmente, e tras o anuncio das autoridades do peche perimetral das sete cidades galegas por mor do agravamento da pandemia, o plenario extraordinario do Día das Letras Galegas celebrouse o 12 de decembro de 2020 no paraninfo da Universidade de Santiago de Compostela (USC), no mesmo edificio en que o homenaxeado impartiu clases como primeiro catedrático de Lingua e Literatura Galega desta institución. 


\section{DE MAIO DE 2020}

O 17 de maio, a Real Academia Galega quixo celebrar o Día das Letras Galegas cunha homenaxe ao pé do que foi o fogar en Santiago de Compostela de Ricardo Carballo Calero, na rúa Carreira do Conde. O acto consistiu nunha sinxela ofrenda floral, á que asistiron o presidente do Parlamento de Galicia, Miguel Santalices; o alcalde de Santiago de Compostela, Xosé Sánchez Bugallo; o conselleiro de Cultura, Román Rodríguez; a subdelegada do Goberno na Coruña, Pilar López-Rioboo Ansorena; e Antonio López, reitor da Universidade de Santiago de Compostela.

No acto interveu o presidente da Real Academia Galega, Víctor F. Freixanes. A continuación, a académica de número Margarita Ledo Andión leu un poema do homenaxeado. A homenaxe rematou coa interpretación do Himno Galego coa compaña de Susana Seivane á gaita.

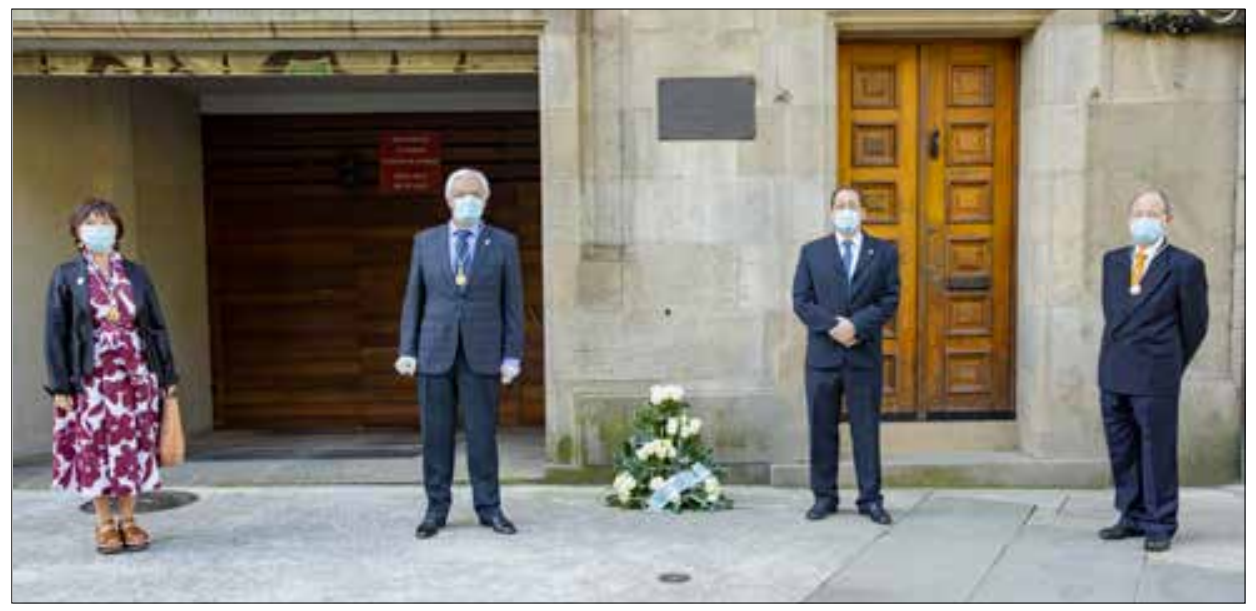

De esquerda a dereita: Margarita Ledo, Víctor F. Freixanes, Henrique Monteagudo e Xesús Ferro Ruibal. Foto: Real Academia Galega.

\section{DE DECEMBRO DE 2020}

O acto central do Ano Carballo Calero, o plenario extraordinario do Día das Letras Galegas, celebrouse o 12 de decembro de 2020 no Paraninfo da Universidade de Santiago.

O presidente da Real Academia Galega, Víctor F. Freixanes, abriu a sesión extraordinaria e pública na que tomaron a palabra os membros de número Margarita Ledo Andión, Ramón Villares Paz e Francisco Fernández Rei. O académico 
Xesús Alonso Montero, cuxa intervención estaba programada, desculpouse pola súa ausencia.

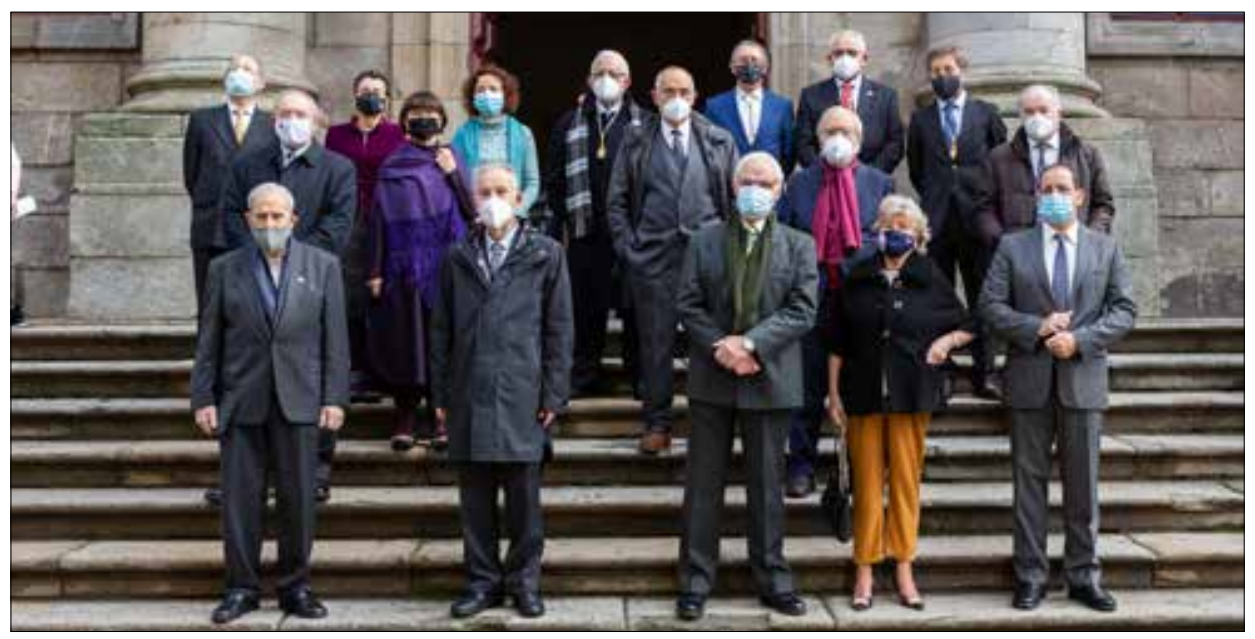

Asistentes ao plenario extraordinario do Día das Letras Galegas.

Foto: Real Academia Galega.

O presidente da Academia abriu o acto coa reivindicación do valor da lingua galega: "Nestes días en que volve discutirse a utilidade dos idiomas e alguén quere reducir a cuestión a termos cuantitativos e excluíntes, a Real Academia Galega reivindica o uso e a presenza da nosa lingua en todos os ámbitos, como fixeron os precursores das Irmandades da Fala, os precursores de Nós: uso e presenza tamén no ámbito educativo, en todas as materias, sen excepcións, pensando moi especialmente nas novas xeracións, ás que debemos dotar de ferramentas e espazos de actividade para o seu desenvolvemento".

Margarita Ledo transitou polos versos dun autor que entendía a poesía como catarse e deixou o máis íntimo da súa personalidade reflectido nela; Ramón Villares trazou a biografía, escrita en tres escenarios centrais -as cidades de Ferrol, Lugo e Santiago de Compostela-, de quen representa "o mellor da cultura galega do século XX”; e Francisco Fernández Rei, alumno do homenaxeado, analizou a evolución da súa visión do idioma, dende o galego autónomo ata o galego reintegrado que defendeu nos últimos anos. Tras a conclusión do pleno, o presidente da RAG cedeu a palabra ao presidente da Xunta de Galicia. A celebración concluíu coa interpretación do Himno de Galicia a cargo da gaiteira Yasmina Farhani. 

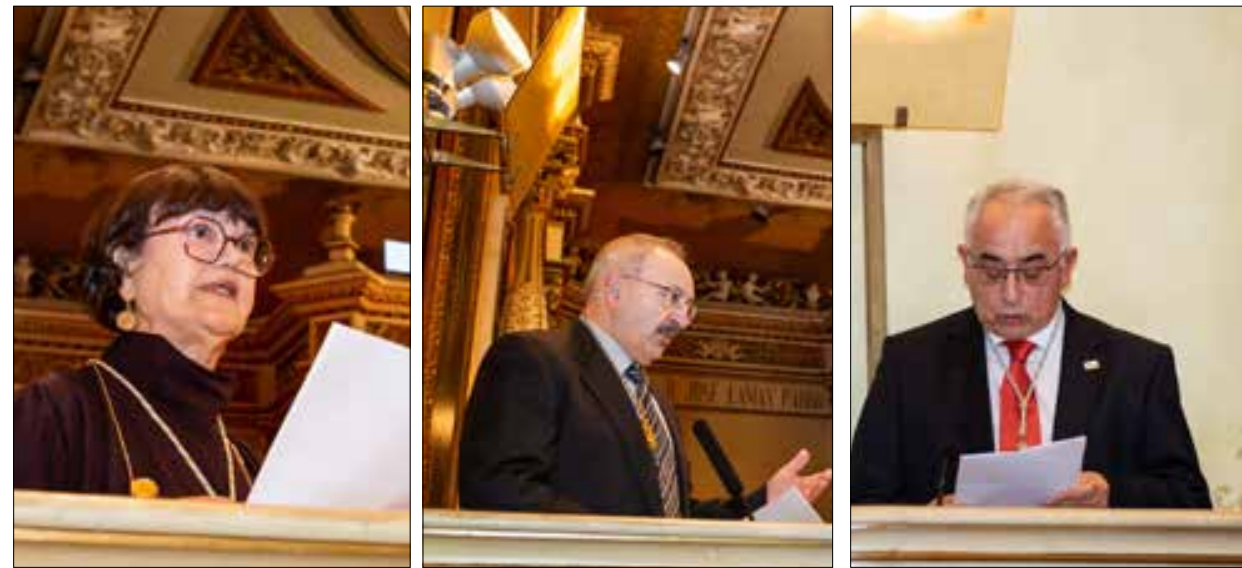

A académica Margarita Ledo Andión e os académicos Ramón Villares e Francisco Fernández Rei durante as súas intervencións. Foto: Real Academia Galega.

\section{SIMPOSIO RICARDO CARBALLO/CARVALHO CALERO}

O Simposio Ricardo Carballo/Carvalho Calero, organizado pola Real Academia Galega coa colaboración da Xunta de Galicia, desenvolveuse no salón de actos da RAG os xoves 8, 15, 22 e 29 de outubro de 2020, ás 19:00 horas. As xornadas puideron seguirse telematicamente a través da páxina web institucional. O programa foi o seguinte:

\section{8 de outubro / Ricardo Carballo Calero no seu tempo}

- No nacionalismo galego de anteguerra / Justo G. Beramendi

- Ricardo Carballo Calero na resistencia dos tempos da guerra e da posguerra (1936-1980) / Carmen Blanco

- O período final (1980-1990) / José-Martinho Montero Santalha

Modera: Ramón Villares

O presidente da Real Academia Galega, Víctor F. Freixanes, e o secretario xeral de Política Lingüística, Valentín García, inauguraron o encontro.

Ramón Villares definiu a Carvalho Calero como "unha persoa que contribuíu a facer a historia de Galicia do século XX e tamén padeceu algunhas das súas adversidades máis fortes". O académico salientou o papel que o autor desempeñou como docente, investigador e difusor da cultura galega fóra de Galicia, de maneira especial en Portugal, ao longo dunha vida vinculada a tres cidades: o seu Ferrol natal; o Santiago dos anos de estudante e a onde volveu en 1965 para converterse no primeiro profesor, e logo catedrático, de Lingüística e Literatura Galega; 
e Lugo, onde Carvalho Calero, vítima da represión franquista, "puido volver á vida pública” en 1950 ao asumir a dirección do acabado de crear Colexio Fingoi.

O catedrático emérito de Historia Contemporánea da Universidade de Santiago de Compostela (USC) Justo Beramendi centrouse no compromiso político de Carballo Calero, unha faciana que amosaría dende a súa chegada a Santiago de Compostela en 1926, cando o nacionalismo, en plena ditadura de Primo de Rivera, vivía momentos complicados. Carvalho Calero exerceu o activismo político "sempre na banda esquerda do movemento, partidaria non só do autogoberno de Galicia, senón tamén da súa democratización en forma republicana [...] Por iso apoiou a estratexia de Castelao e Alexandre Bóveda e foi partidario da entrada do Partido Galeguista na Fronte Popular. Presidiu a asemblea extraordinaria do PG en que se aprobou a devandita entrada e contribuíu á elección de Manuel Azaña como presidente da República en 1936”.

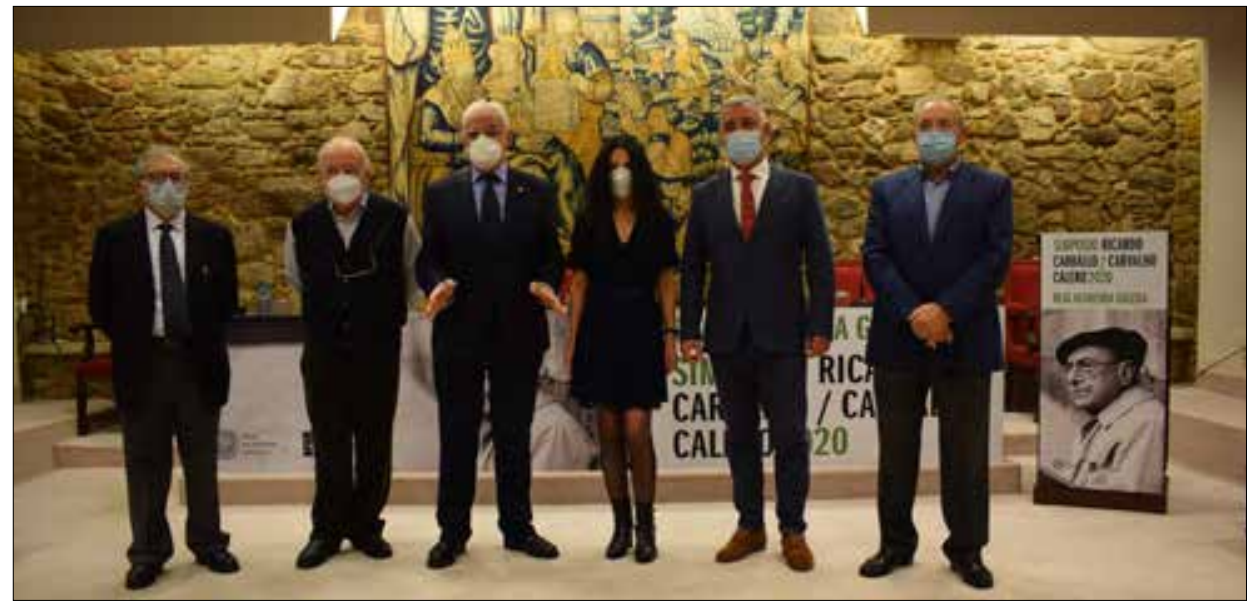

A profesora de Filoloxía Galega da Facultade de Humanidades de Lugo Carmen Blanco foi a encargada de abordar os anos "na resistencia" da guerra e do exilio interior, da posguerra e a transición. Carvalho Calero loitou no exército republicano, foi condenado a prisión polas forzas franquistas e, unha vez en liberdade provisoria, estivo inhabilitado durante anos para exercer empregos públicos. Malia o difícil contexto, "conduciu afirmativamente a súa profunda e precoz vocación literaria e a súa ansiada vocación profesoral”, primeiro no ensino privado, de maneira especial no Colexio Fingoi, onde Carmen Blanco o coñeceu como docente sendo só unha nena; e despois na universidade pública.

José Martinho Montero Santalha pechou a primeira sesión do simposio co retrato dos dez últimos anos de vida de Carvalho Calero (1980-1990). Estes foron os anos en que publicou obras esenciais na formulación da súa perspectiva sobre 
a lingua, reeditou a súa produción literaria anterior e compuxo "algunhas das súas mellores obras", tanto de narrativa (Scórpio, 1987) como de poesía (Cantigas de amigo e outros poemas, 1986; Reticências..., 1990) e de teatro (Os xefes, 1980), sintetiza o profesor da Universidade de Vigo.

\section{5 de outubro / Estudos sobre literatura}

- Contribucións á canonización da narrativa galega / Dolores Vilavedra

- O tratamento do xénero poético en RCC. Crítica literaria, canon e historiografía / Alberte Valverde

- Os estudos de Ricardo Carvalho Calero sobre Rosalía de Castro: unha achega maxistral / María Pilar García Negro

Modera: Marilar Aleixandre

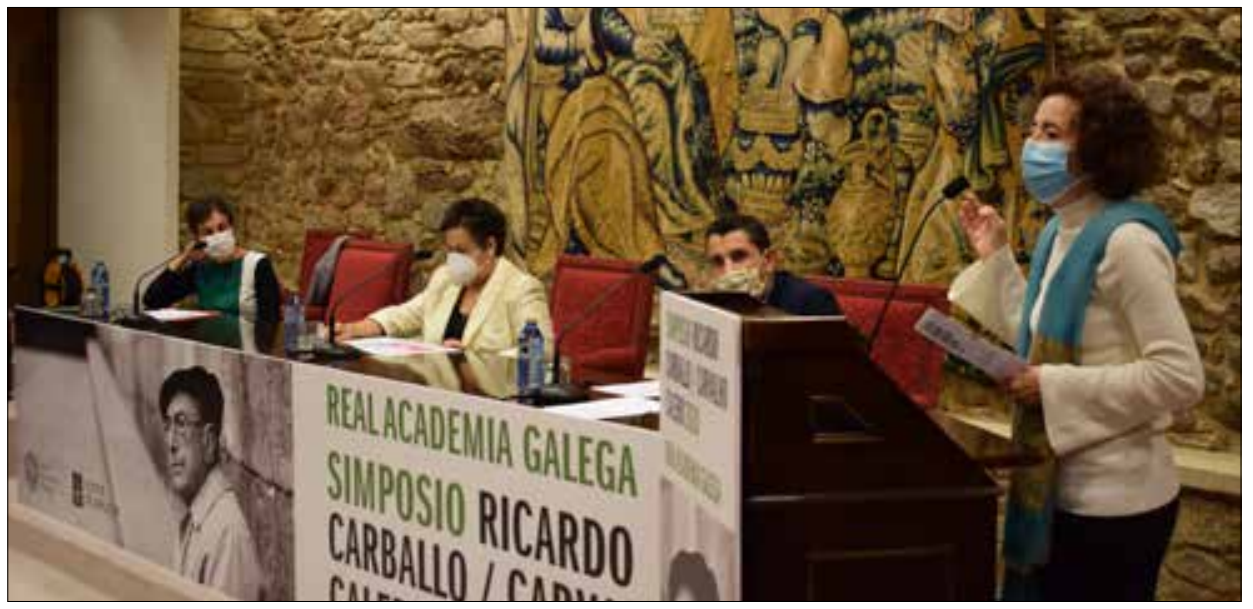

$\mathrm{Na}$ segunda xornada, a profesora da Universidade de Santiago de Compostela Dolores Vilavedra analizou as contribucións á canonización da narrativa. A profesora considera que a actuación canonizadora do autor no relativo á narrativa galega estivo, de feito, sempre mediatizada polos seus prexuízos, dende os identitarios aos lingüísticos. $\mathrm{O}$ autor non amosou moito interese pola narrativa ficcional, que consideraba un xénero secundario fronte á poesía. A súa obra como crítico deixa patente, en calquera caso, a súa preferencia polas formas narrativas breves e a "alta consideración canónica que sempre lle mereceron Castelao, Otero Pedrayo e, nun segundo nivel, Vicente Risco".

Alberte Valverde incidiu na Historia da literatura galega contemporánea nunha intervención sobre a produción crítica e historiográfica do autor referida ao discurso poético, que arrinca nos seus anos de mocidade e nas súas publicacións na 
revista Nós. O investigador realizou unha viaxe polos textos ensaísticos que o profesor publicou entre 1931 e 1981, incidindo en conceptos como nacionalismo literario, literatura nacional e canon.

"Rosalía de Castro foi parte das primeiras lecturas de Carvalho Calero e ela tamén o acompañou na súa despedida”, resume Pilar García Negro, que centrou o seu relatorio nos estudos do autor sobre a escritora. $\mathrm{O}$ seu derradeiro artigo, publicado postumamente, ten a Rosalía por obxecto e pecha dalgún xeito un círculo que comezara no poema "Madrigal a Rosalía", publicado n’O silenzo axionallado (1934), xustifica a profesora. Máis de medio século separa ambos os textos, unidos por centos de páxinas dedicadas por Carvalho Calero ao estudo, á análise, á interpretación e mais á divulgación de Rosalía de Castro.

\section{2 de outubro / Creación literaria}

- Poesía e ficcións do eu / Pilar Pallarés

- Ricardo Carvalho Calero, dramaturgo / Laura Tato

- Carvalho Calero narrador. Scórpio e as mulleres / Henrique Rabuñal

Modera: Margarita Ledo

A poeta e antóloga de Carvalho Calero Pilar Pallarés profundou nas ficcións do eu na obra do autor poñendo o foco no xénero co que se sentiu máis identificado, a poesía, unha arte que concibía como catarse. Na súa intervención trazou un percorrido polos seus poemarios na procura dos materiais procedentes das vivencias de Carvalho Calero e analizou algunhas das súas estratexias de ficcionalización do eu: as máscaras do suxeito lírico, o discurso irónico e o mito.

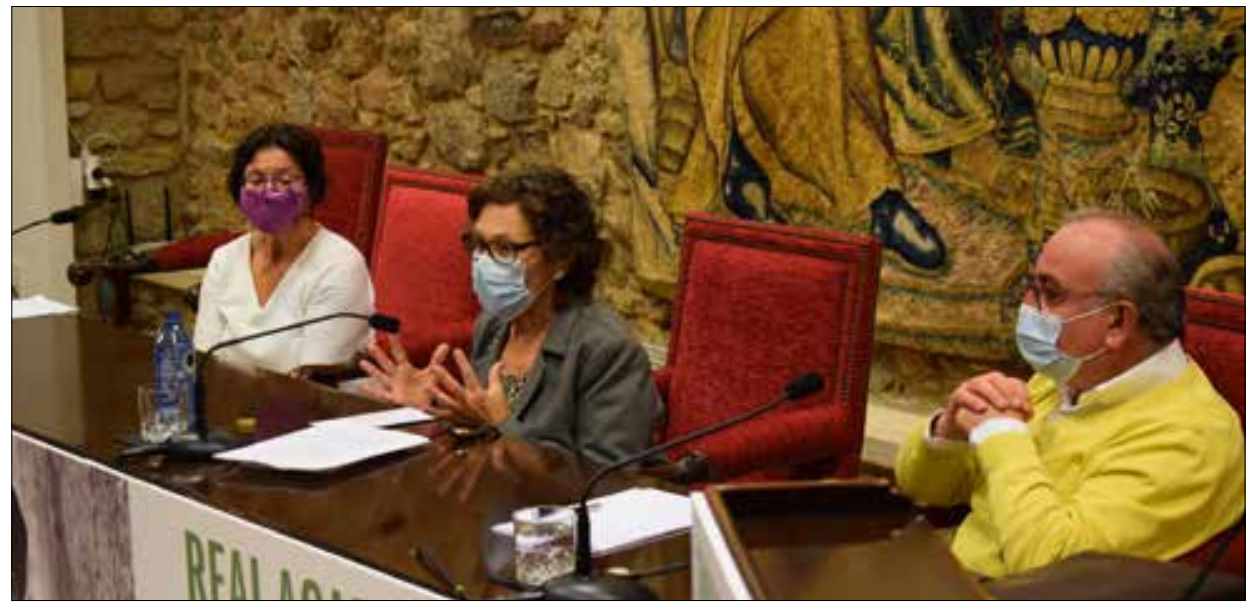


A produción como dramaturgo de Ricardo Carvalho Calero foi abordada pola catedrática de Filoloxías Galega e Portuguesa da Universidade da Coruña Laura Tato Fontaína. A súa traxectoria como autor teatral comezou cando o Partido Galeguista, na Asemblea celebrada en Ourense (1934), encargou ás Mocidades Galeguistas un relatorio sobre o teatro galego, e concluíu en 1980 coa súa derradeira e "mellor peza", Os xefes (1980), na que deixou "unha homenaxe ao Castelao d'Os vellos non deben de namorarse e mais unha profunda reflexión sobre o poder".

O escritor e profesor Henrique Rabuñal, autor da biografía Ricardo Carvalho Calero. O anxo da terra (2020), puxo o acento na orixinalidade técnica e nas achegas estilísticas da novela Scórpio (1987). O éxito desta obra radica no que ten de "reflexión e memoria individual e colectiva para o período 1910-1939, nunha interacción premeditada entre ficción e memoria e nunha meditación sobre a guerra e as súas consecuencias para a xeración de Carvalho e para os seus ideais".

\section{9 de outubro / Ideas e achegas ao idioma}

- Ideario lingüístico de Ricardo Carballo Calero sobre o galego (1950-1965) / Henrique Monteagudo

- A liña do galego literario na gramática de Carballo Calero / Serafín Alonso Pintos

- O ideário de Ricardo Carvalho Calero no reintegracionismo do século XXI / Eduardo Maragoto

\section{Modera: Rosario Álvarez}

As ideas e as achegas ao idioma do protagonista do Día das Letras Galegas 2020 centraron a cuarta e derradeira xornada do Simposio Ricardo Carballo / Carvalho Calero. Os tres relatores, o académico Henrique Monteagudo, o profesor e investigador Serafín Alonso Pintos e o presidente da Associaçom Galega da Língua, Eduardo Maragoto, abordaron as distintas etapas do autor homenaxeado dende a perspectiva do proceso de formación do galego escrito moderno, tanto dende o punto de vista da norma gramatical como da configuración do estándar gráfico. A directora da Sección de Lingua da Academia, Rosario Álvarez, moderou unha sesión na que se puxeron de manifesto as ideas lingüísticas do autor, "cambiantes ao longo do tempo", dende unha primeira etapa que desemboca no momento en que accedeu ao posto de profesor universitario (1965) ata a final, máis tardía, "marcada polo reintegracionismo, afastado do ideario inicial compartido polos seus compañeiros de xeración”, introduciu a académica.

Henrique Monteagudo abordou o labor como filólogo de Carvalho Calero entre 1950 e 1971 no marco do grupo Galaxia, "do que foi un dos máis significativos intelectuais". Alén de fixar o canon clásico coa súa Historia da literatura 
galega contemporánea (1963), tamén colaborou nas estratexias relativas a dúas institucións que Galaxia considerou chaves para a defensa da lingua e da cultura galegas: a Universidade, onde se converteu no curso 1965-1966 no primeiro profesor de lingua e literatura galegas, e a RAG. Nos 60, xa como primeiro profesor de galego da Universidade, Carvalho Calero fixo "un esforzo titánico" e redactou nun tempo récord a Gramática elemental del gallego común (1966).

Serafín Alonso Pintos detívose no modelo de galego que se debuxa na Gramática, unha obra que coñeceu sete edicións e onde se establece "un sutil e criterioso diálogo coa tradición do galego escrito literario". O manual editado por Galaxia toma, de feito, os seus exemplos dos clásicos do século XIX, con Rosalía á fronte, e defende na primeira edición un espazo propio no ámbito ibérico para o galego común fronte aos grandes estándares estatais castelán e portugués, explica o investigador.

Eduardo Maragoto repasou a evolución de Ricardo Carvalho Calero cara a unha crecente proximidade ao portugués, que quedou tamén patente no seu traballo como presidente da comisión lingüística da Xunta de Galicia que elaborou en 1979 as primeiras normas do galego en democracia. A partir de 1981 o profesor comezaría a escribir no que pasou a ser coñecido como galego reintegrado, adoptando a maioría dos trazos fundamentais da ortografía portuguesa. Pero xa en 1975 escribira os primeiros de moitos artigos nos que defendía unha ortografía converxente co portugués, publicados en La Voz de Galicia.

O presidente da Real Academia Galega, Víctor F. Freixanes, foi o responsable da clausura deste simposio. 


\section{PRIMAVERA DAS LETRAS DEDICADA A RICARDO CARBALLO CALERO}

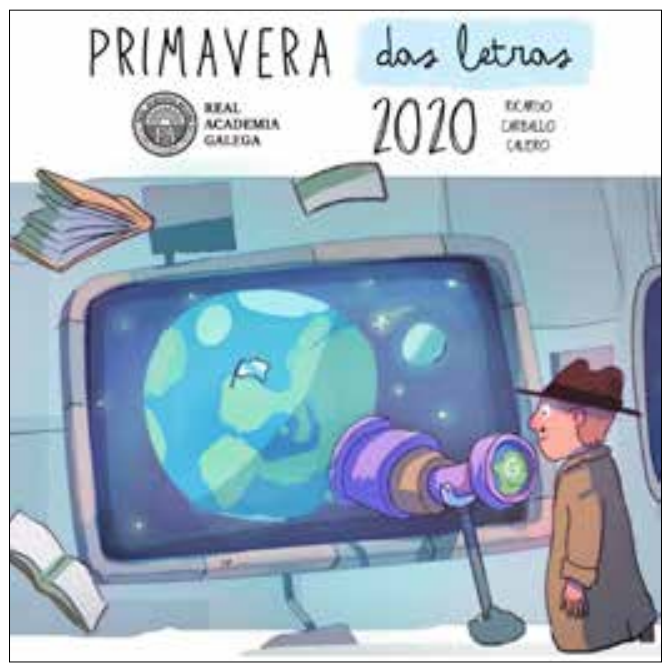

O 11 de febreiro de 2020, a Real Academia Galega presentou no CEIP Cruceiro de Canido (Ferrol) o sitio web Primavera das Letras 2020 dedicado a Ricardo Carballo [Carvalho] Calero.

A institución ofrece a través deste espazo na Rede de acceso libre, primaveradasletras.gal, contidos lúdicos e didácticos que achegan a vida e a obra do protagonista do Día das Letras Galegas 2020 aos nenos e nenas de infantil e primaria. Os primeiros materiais dispoñibles trazan unha biografía do homenaxeado, ofrecen unha visión de conxunto da súa obra como creador literario, detéñense tamén na súa Historia da literatura galega contemporánea e convidan a saber máis sobre a súa cidade natal, Ferrol, e o teatro e a ópera, dúas das súas grandes afeccións. As propostas inclúen tanto actividades interactivas como fichas descargables para xogar e aprender sen necesidade de conexión a Internet, relacionando o universo vital e intelectual de Ricardo Carballo Calero con distintos aspectos do currículo escolar. A web enriqueceuse ao longo do ano con recursos sobre a poesía de Carballo Calero, a cidade de Lugo, onde viviu quince anos, ou a lusofonía. O proxecto completouse co concurso escolar Contádenos o voso Día das Letras, que premiou un ano máis as mellores propostas dos centros educativos arredor do 17 de maio.

A presentación de Primavera das Letras, conducida pola directora do CEIP Cruceiro de Canido, Concepción Requejo, tivo como protagonistas os alumnos e alumnas do colexio, que lembraron o homenaxeado cunha representación teatral e musical. Por parte da Academia interviñeron o presidente, Víctor F. Freixanes, e 
a académica Fina Casalderrey. $\mathrm{O}$ acto contou coa presenza do alcalde da cidade, Ángel Mato, e o concelleiro de Educación, Antonio Golpe.

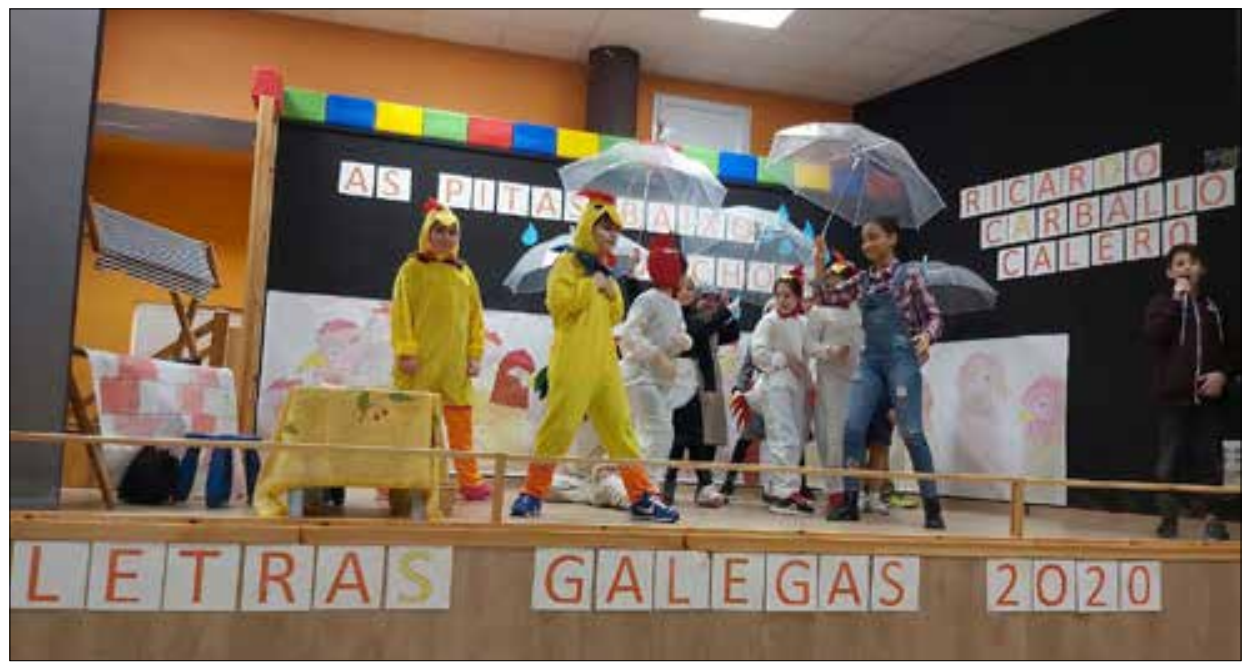

Os rapaces e rapazas de $5^{\mathrm{O}}$ e $6^{\mathrm{O}}$ trazaron sobre o escenario un percorrido pola biografía do autor, recitaron versos da súa autoría e fragmentos da súa primeira novela, A xente da Barreira, e ofreceron unha representación do seu conto "As pitas baixo a choiva”, do que tamén fala a Primavera das Letras.

En plena crise sanitaria, esta web da Real Academia Galega experimentou un incremento no número de consultas de contidos con respecto ao ano anterior por riba do 180 \% durante o mes de maio, achegándose ás 300.000 páxinas vistas. Durante o confinamento, duplicouse ademais o acceso a través dos teléfonos móbiles, que representou un 30 \% do total. As visitas a Primavera das Letras disparáronse a partir da última semana do mes de abril e só no mes de maio o portal rexistrou máis consultas ca en todo o ano 2019.

Os recursos máis empregados foron as fichas descargables sobre a vida do autor, Letras para contar un país; sobre a súa obra, De Vieiros a Scórpio; e a dedicada ao seu labor como autor da Historia da literatura galega contemporánea, $\mathrm{O}$ buscador de libros. A actividade interactiva máis repetida foi a que xira arredor do relato "As pitas baixo a chuvia", seguida das dedicadas a Ferrol, cidade natal do autor; aos poemas e os idiomas e a dúas grandes afeccións de Carballo Calero, o teatro e mais a ópera. Entre os materiais máis demandados tamén aparecen as fichas para colorear. 
O proxecto complétase co concurso escolar Contádenos o voso Día das Letras, que premia as mellores propostas dos centros educativos arredor do 17 de maio. Neste ano de pandemia, o prazo para participar no concurso ampliouse ata o 1 de decembro de 2020.

Un total de oitenta centros de educación infantil e primaria de toda Galicia concorreu á última edición de Contádenos o voso Día das Letras. Videoclips, festivais virtuais, programas de radio, xogos de investigación, recitado de poemas e debuxos para ilustrar a obra do autor son algunhas das propostas presentadas no concurso. Os traballos recollen tanto actividades desenvolvidas durante o confinamento, centradas en experiencias virtuais, como outras presenciais, todas elas cunha clara compoñente lúdica como clave para achegar o público de 3 a 11 anos á vida e mais á obra de Ricardo Carvalho Calero. Todos os traballos poden verse na páxina web de Primavera das Letras.

O concurso resolveuse a comezos do mes de xaneiro. Os colexios Saco e Arce de Toén (Ourense), Juan Fernández Latorre (A Coruña) e Marcos da Portela (Pontevedra) foron os gañadores da última edición. Os tres centros participaron con traballos arredor da vida e da obra de Ricardo Carballo Calero que implicaron a participación do alumnado e das familias durante o confinamento e a desescalada, e que constitúen unha boa mostra do esforzo que realizou o conxunto da comunidade educativa galega para celebrar as Letras Galegas 2020 en plena pandemia. Tampouco faltaron materiais elaborados polo profesorado para facilitar a celebración dende os fogares. Os colexios gañadores foron premiados con lotes de libros para dotaren as súas bibliotecas.

O CEIP Saco e Arce de Toén participou cunha das iniciativas máis orixinais para achegar os nenos e nenas á vida e á obra de Carballo Calero. O profesorado animou o alumnado a profundar na súa vida e no seu legado literario e a localizar en Ourense a rúa dedicada ao filólogo e escritor. Unha vez atopada, os nenos e nenas deixaron nela debuxos, poemas e outras creacións a modo de homenaxe. O resultado pode verse nun vídeo de resumo no que Xoana fala da súa lectura de "As pitas baixo a chuvia", Pablo e a súa nai len un fragmento do mesmo relato, e Noa, Aixa e Luán recitan versos do escritor na rúa a el dedicada.

As contribucións do CEIP Juan Fernández Latorre son outro bo exemplo do gran labor do profesorado e das familias durante o confinamento para facer realidade a celebración das Letras Galegas. Entre outras propostas, o alumnado de 5 anos gravou dende a casa unha dramatización do devandito relato, inspirado na infancia do autor e moi empregado nas aulas do alumnado de infantil o do primeiro ciclo de primaria de toda Galicia pola súa idoneidade para estas etapas. O equipo de dinamización lingüística tamén se implicou de cheo na celebración e preparou dous xogos sobre Carballo Calero, baseados no xogo da ruleta e nos birlos. 
Os fogares foron de igual xeito o escenario da celebración das Letras Galegas 2020 da comunidade educativa do CEP Marcos da Portela. O alumnado deste colexio pontevedrés percorre a biografía de Carballo Calero, recita poemas e le outros fragmentos da súa obra nun dos vídeos gravados durante o confinamento, no que tamén participa o profesorado. Outra peza ofrece unha adaptación do relato "As pitas baixo a chuvia", neste caso da intérprete de lingua de signos do centro; e o equipo de dinamización lingüística preparou tres Pasapalabras sobre o autor adaptados a cada un dos ciclos de primaria.

Todos os colexios participantes recibiron un diploma que acredita a súa achega á celebración das Letras Galegas do escritor, filólogo e profesor ferrolán.

\section{UNHA PALABRA PARA DON RICARDO}

A Real Academia Galega programou para o mes de maio a serie Unha palabra para don Ricardo, un conxunto de minipezas audiovisuais arredor da figura de Ricardo Carballo Calero que conforman un retrato colectivo do protagonista do Día das Letras Galegas 2020. Os microespazos puideron verse a través da web e das redes sociais da institución e tamén foron difundidos pola CRTVG.

Unha palabra para don Ricardo contou coa participación de académicos e académicas de número, académicos correspondentes e distintas persoas que tiveron algunha relación co autor. Cada participante escolleu unha palabra que destacase a calidade que, ao seu xuízo, mellor definise o homenaxeado ou que retratase un trazo persoal, unha faceta ou unha obra do autor que valorase especialmente. Compromiso, galego cabal, poeta, filólogo, galeguista, soñador, lingua, gramática, orador ou independente son algúns dos termos a través dos cales foron debuxando un retrato colectivo de Carballo Calero.

\section{UNHA PALABRA PARA DON RICARDO}

1/N/2020 Salvador García-Bodaño

2/V/2020 Margarita Ledo

3/V/2020 Henrique Monteagudo

4/V/2020 Rosario Álvarez Blanco

5/V/2020 Claudio Rodríguez Fer

6/V/2020 Fina Casalderrey

7/V/2020 Antón Santamarina

8/V/2020 Araceli Herrero

9/V/2020 Francisco Fernández Rei
Didáctica

Corpo

Grial

Gramática

Independente

Lectura d'A xente da Barreira

Orador

Galeguista

Literatura 
10/V/2020 Gonzalo Navaza

11/V/2020 Ramón Villares

12/V/2020 Pilar García Negro

13/V/2020 Xosé Luís Regueira

14/V/2020 Xesús Alonso Montero

14/V/2020 Carmen Blanco

15/V/2020 Gonzalo Navaza

15/V/2020 José Luís Rodríguez

16/V/2020 Henrique Monteagudo

16/V/2020 Manuel González

17/V/2020 Víctor F. Freixanes

17/V/2020 Ana Romaní

18/V/2020 Francisco Cidrás

19/V/2020 Eduardo Maragoto

20/V/2020 Andrés Torres Queiruga

21/V/2020 Darío Villanueva

22/V/2020 Mercedes Queixas Zas

23/V/2020 Martinho Montero

24/V/2020 Margarita Ledo

24/V/2020 Manuel Rivas

25/V/2020 Pilar Pallarés

26/V/2020 Fina Casalderrey

27/V/2020 Goretti Sanmartín

28/V/2020 Fernando López-Acuña

29/V/2020 Euloxio Rodríguez Ruibal

30/V/2020 Henrique Rabuñal

31/V/2020 Víctor F. Freixanes
Requintado

As distintas biografías de Carballo Calero

Galego cabal

Vulto

República

Poeta

Pondal na Historia da literatura galega contemporánea

Compromiso

Recitado de "Esta casa que ninguén visita"

Gramática

Declaracións do presidente da Real

Academia Galega no Día das Letras

Galegas de Carballo Calero

Recitado de "Como pudemos"

Compromiso

Comunicación con outros países

Transcendencia

Filólogo

Sorpresa

Compromiso

Lectura de "Feminismo e galeguismo"

Vangardista

Xigante

Soñador

Lingua

Fingoi

Teatro

Galiza

Profesor 


\section{OUTRAS ACTIVIDADES CO GALLO DO DÍA DAS LETRAS GALEGAS DEDICADO A RICARDO CARBALLO CALERO}

\section{0 de xaneiro de 2020. María Victoria Carballo Calero visita a RAG}

O 10 de xaneiro de 2020 a filla do protagonista do Día das Letras Galegas visitou a sede da Real Academia Galega. Na xuntanza que mantivo coa Comisión Executiva repasaron o calendario de actos e iniciativas previstas para divulgar ao longo de 2020 o legado de Ricardo Carballo Calero.

\section{5 de xaneiro de 2020. Inauguración da exposición Don Ricardo de Fingoi}

O presidente da RAG, Víctor F. Freixanes participou na inauguración desta exposición, organizada polo Colectivo Egeria, que repasa os quince anos durante os que Ricardo Carballo Calero residiu en Lugo, a onde se desprazou para poñerse á fronte do Colexio Fingoi. A mostra contou co apoio da Consellería de Cultura e a colaboración da Real Academia Galega e o Colexio Fingoi. O presidente da Academia participou na inauguración da mostra xunto ao seu coordinador, Xulio Xiz; Margarita Carballo, filla do homenaxeado; Asunción Fernández e Pilar Martínez Conde Pilocha, directora e profesora de canto do colexio, respectivamente; María Dolores Fernández, alumna de Carballo Calero neste centro e posteriormente compañeira del na Universidade de Santiago de Compostela; e o secretario xeral de Política Lingüística, Valentín García. Jacobo Cela, neto de Ricardo Carballo Calero, interpretou unha peza ao violín nun acto que foi tamén amenizado polos Gaiteiros de Fingoi dirixidos por Pepe Vaamonde.

Ademais da mostra, o colectivo Egeria editou o libro Carballo Calero en Lugo. Don Ricardo de Fingoi, que xunta máis dunha trintena de colaboracións de antigos alumnos e alumnas e amizades de Carballo Calero.

\section{4 de xaneiro de 2020. Presentación da mostra Ricardo Carvalho Calero}

O presidente da RAG, Víctor F. Freixanes, participou en Ferrol na presentación desta exposición, organizada polo Concello de Ferrol para conmemorar o centenario do nacemento do autor e composta por vinte e catro paneis que ofrecen un percorrido pola súa vida e obra. No acto participaron tamén Delia Vázquez, alumna de Carvalho Calero e estudosa da súa figura, Margarita Carballo Ramos, primoxénita de don Ricardo, e Ángel Mato, alcalde da cidade.

17 de febreiro de 2020. Presentación do calendario de actos do ano Carballo Calero

O presidente da RAG participou na presentación da programación das Letras Galegas 2020, celebrada en Santiago de Compostela, canda o conselleiro de Cultura, Román Rodríguez; a secretaria do Consello da Cultura Galega, Dolores Vilavedra; as fillas do homenaxeado, Margarita Carballo Ramos e María Victoria 
Carballo-Calero; o presidente da Associaçom Galega da Língua, Eduardo Sanches Maragoto; a responsable de RSC da CRTVG, Marta Fernández Sánchez; a tenente de alcalde do Concello de Santiago de Compostela, Mercedes Rosón; e o tenente de alcalde do Concello de Ferrol, Antonio Golpe Díaz. O acto tamén contou entre o público convidado con representantes de distintas asociacións, entidades e empresas que colaborarían ou conmemorarían dalgún xeito as Letras Galegas de Carvalho Calero.

\section{5 de marzo de 2020. Carvalho Calero no programa A Trabe de Ouro}

Cadrando co cabodano do pasamento de Ricardo Carbalho Calero, a Real Academia Galega compartiu o capítulo do programa cultural A Trabe de Ouro da Televisión de Galicia que o escritor, filólogo e profesor protagonizou no ano 1987. O espazo, conducido por Víctor F. Freixanes, actual presidente da RAG, inclúe unha entrevista ao autor na que fala sobre a súa xeración, a súa obra literaria e a lingua.

\section{7 de setembro de 2020. Inauguración de Carvalho Calero. A voz presente}

O presidente da Real Academia Galega, Víctor F. Freixanes, participou na inauguración na biblioteca Miguel González Garcés da exposición organizada pola Associaçom Galega da Lingua (AGAL), co apoio da Xunta de Galicia, que ofrece un percorrido pola vida do protagonista do Día das Letras Galegas 2020 e se detén nos espazos que marcaron a súa traxectoria, as circunstancias políticas que rodearon a súa obra, o seu labor como creador literario, o seu traballo como filólogo e o seu ideario lingüístico.

Víctor F. Freixanes participou na visita á mostra canda o secretario xeral de Política Lingüística, Valentín García; os directores xerais de Políticas Culturais e de Patrimonio Cultural, Anxo M. Lorenzo e M.르 Carmen Martínez Ínsua; a filla do autor homenaxeado Margarita Carballo Ramos; o presidente da AGAL , Eduardo Sanches Maragoto, e a directora da biblioteca González Garcés, Marisol González.

Esta exposición continuou a súa andaina por diversas vilas e cidades galegas.

1 de outubro de 2020. Presentación do libro Ricardo Carvalho Calero, orador. Discursos e leccións

O presidente da Academia, Víctor F. Freixanes, participou na presentación do volume escrito por Pilar García Negro e editado polo Parlamento de Galicia. Na presentación interviñeron canda el o presidente do Parlamento, Miguel Santalices; a autora; familiares de Carballo Calero; e o secretario xeral de Política Lingüística da Xunta de Galicia, Valentín García.

No acto inaugurouse tamén unha mostra bibliográfica que amosou por orde cronolóxica medio cento de libros e mais documentos persoais de Carballo Calero, 
como o carné de socio do Seminario de Estudos Galegos e dúas cartas de Otero Pedrayo.

\section{5 de novembro de 2020. Maratón de lectura do Día das Letras Galegas orga- nizado pola Fundación Granell}

O presidente da Real Academia Galega participou na inauguración desta cita canda a concelleira de Acción Cultural do Concello de Santiago de Compostela, Mercedes Rosón; a xerente do Consorcio de Santiago, Belén Hernández; a deputada provincial Milagros Castro; o concelleiro José Antonio Constenla Ramos; o secretario xeral de Cultura, Anxo Lorenzo; e os veciños e veciñas de Santiago de Compostela. Víctor F. Freixanes escolleu os versos que Carvalho Calero lle dedicou a Álvaro Cunqueiro, compañeiro tamén de xeración e amigo dende os anos universitarios en Santiago de Compostela.

15 de xaneiro de 2021. Presentación de Polos camiños das horas. Epistolario de Ricardo Carballo Calero e Ramón Otero Pedrayo

O epistolario - publicado co apoio do propio Parlamento e da Consellería de Cultura- foi editado por Patricia Arias Chachero, Adrián Estévez Iglesias e Nélida Cosme e coordinado polo académico Henrique Monteagudo. A súa presentación celebrouse no Hórreo e nela interviñeron o presidente da Real Academia Galega, Víctor F. Freixanes; o presidente do Parlamento de Galicia, Miguel Santalices; Victoria Carballo-Calero, filla do protagonista das Letras Galegas 2020; Román Rodríguez, titular da Consellería de Cultura; Henrique Monteagudo e Patricia Arias Chachero.

\section{O Instituto Arxentino Galego Santiago Apóstolo celebra a Carvalho Calero dende o confinamento}

O centro educativo porteño, dirixido polo académico correspondente Carlos Brandeiro, pechou as portas por mor do coronavirus pouco despois de comezar o novo curso escolar, pero Ricardo Carvalho Calero non quedou sen homenaxe. As profesoras Marta Villar e Alejandra Lorenzo concibiron e dirixiron dende o confinamento o tradicional acto protagonizado polo alumnado que, desta volta, se converteu en virtual. Os mozos e mozas participantes gravaron cos seus teléfonos móbiles as distintas partes da función dixital, que conclúe cun videoclip que converte en canción a ritmo de trap o poema de Carvalho Calero "Teño unha dor". O resultado, que pode verse nas redes sociais do colexio, foi unha experiencia enriquecedora para o alumnado e moi ben recibido pola comunidade galega en Arxentina. 


\section{Carballo Calero na biblioteca da Academia}

A biblioteca da Real Academia Galega homenaxeou o autor amosando na sala de consulta, durante todo o ano, unha selección de primeiras edicións da súa obra que forman parte dun conxunto bibliográfico máis amplo a disposición dos usuarios na rúa Tabernas. A colección da biblioteca da RAG arredor do autor ferrolán é moito máis extensa e inclúe, entre outros fondos, artigos publicados en distintas revistas custodiadas na hemeroteca, como os publicados na revista Nós ou no Boletín da institución, ademais das obras arredor da biografía do homenaxeado.

\section{Entrevistas con máis vagar}

A sección das Letras Galegas de academia.gal é a fiestra dende a cal a RAG reúne diversos contidos dirixidos á divulgación da figura do homenaxeado no Día das Letras Galegas. O espazo acubilla a serie de micropezas audiovisuais Unha palabra para don Ricardo, e tamén unha serie de entrevistas que pretenden abordar con máis vagar e profundidade os perfís literarios do autor: Pilar Pallarés, Carmen Blanco, Dolores Vilavedra, Laura Tato, Henrique Rabuñal, Héctor Cajaraville, Xosé María Dobarro e Asunción Fernández, completan a lista dos entrevistados.

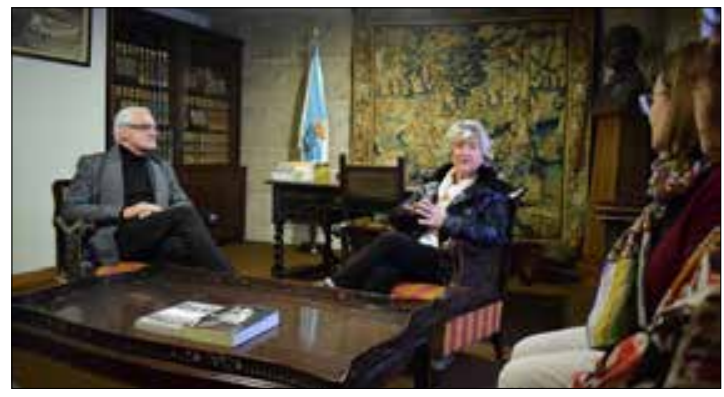

María Victoria Carballo Calero visita a RAG. 10 de xaneiro de 2020. Foto: RAG

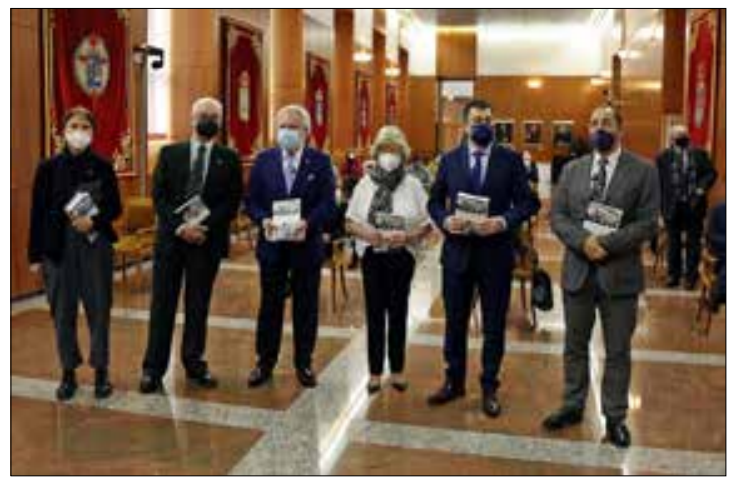

Presentación de Polos camiños das horas. Epistolario de Ricardo Carballo Calero e Ramón Otero Pedrayo. 15 de xaneiro de 2021. Foto: RAG. 


\section{CONCURSO DE MICRORRELATOS DA REAL ACADEMIA GALEGA E A ASOCIACIÓN PUNTOGAL}

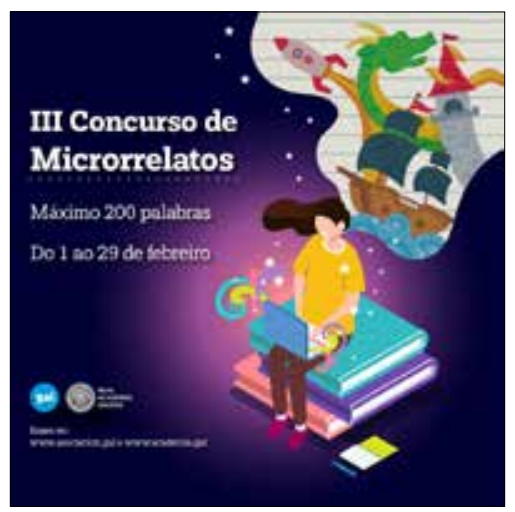

A Real Academia Galega e a Asociación PuntoGal presentaron o 28 de xaneiro de 2020 a terceira edición do concurso de microrrelatos convocado por ambas as entidades co obxectivo de reforzar o uso da lingua galega en Internet.

O número de participantes en 2020 foi de 765 persoas, distribuídas nas categorías de infantil (120 microrrelatos presentados), xuvenil (232) e adultos (413).

O presidente da Real Academia Galega, Víctor F. Freixanes; o presidente de PuntoGal e académico de número, Manuel González; a académica de número Ana Romaní; o director xeral de PuntoGal, Darío Janeiro; e a xornalista Claudia Morán, membro do comité de redacción de Luzes, conformaron o xurado que resolveu a terceira convocatoria de forma telemática. Aínda que a resolución do concurso estaba programada para finais de abril, debido a atrancos derivados das medidas de confinamento pola pandemia de coronavirus, pospúxose ao 4 de xuño.

Cristina Fernández Mangana, co relato "A tía Ramona", fíxose co primeiro premio na modalidade de adultos. Nee Barros Fernández acadou o primeiro premio da categoría xuvenil con "Entre a vida e a morte". Este foi o seu segundo galardón neste certame, xa que tamén merecera un premio na primeira edición. "Un mundo máxico", de Christian Cabaleiro Otero, foi o relato gañador do primeiro premio na categoría infantil.

As nove persoas premiadas recibiron diferentes premios de perfil tecnolóxico, libros e, no caso dos primeiros e segundos premios, un dominio gal gratuíto durante un ano. A Real Academia e PuntoGal publicaron os textos seleccionados nas súas páxinas web e a revista Luzes reproduciu unha escolma dos relatos participantes e agasallou as persoas gañadoras na modalidade de adultos cun lote de publicacións da revista. 


\section{XORNADA DE ONOMÁSTICA GALECA: OS NOMES COMERCIAIS}

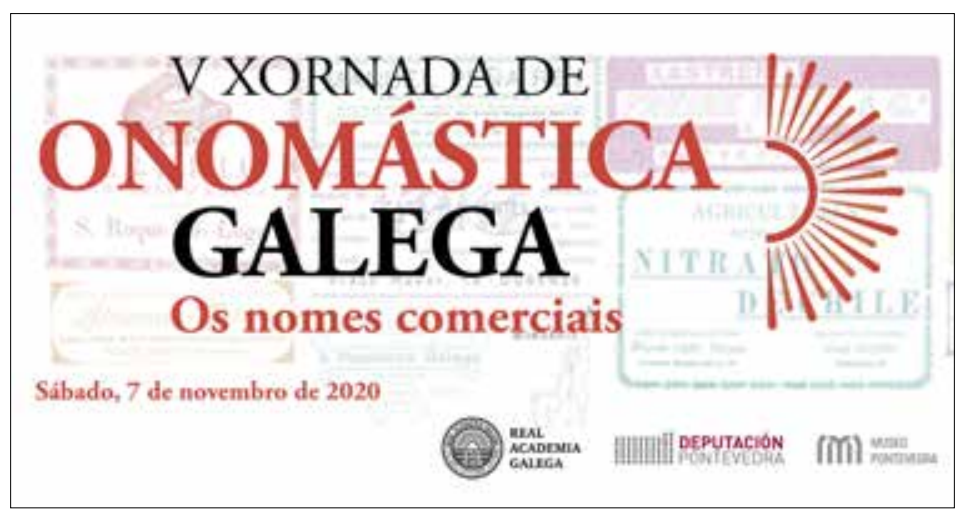

A V Xornada de Onomástica Galega foi organizada pola Real Academia Galega coa colaboración da Excma. Deputación Provincial de Pontevedra e o Museo de Pontevedra. O comité organizador estivo formado polas académicas correspondentes Ana Isabel Boullón Agrelo e Luz Méndez, que desenvolveron tamén o rol de coordinadoras.

Na programación inicial estaba previsto o desenvolvemento da xornada no Edificio Sexto do Museo de Pontevedra o 7 de novembro de 2020. Mais o 3 de novembro, tras o anuncio da Xunta de Galicia de medidas que limitaban a mobilidade das persoas por mor do agravamento da pandemia da covid-19, a Real Academia Galega viuse na obriga de suspender a celebración da V Xornada de Onomástica Galega de maneira presencial e convocala exclusivamente de xeito telemático. Todo o programa, tal e como xa estaba previsto, foi emitido en directo a través da páxina web da Real Academia Galega, academia.gal, e a través da plataforma Zoom para aquelas persoas que desexaban obter o certificado de asistencia.

A V Xornada de Onomástica Galega foi inaugurada de maneira virtual polo presidente da Real Academia Galega, Víctor F. Freixanes, a deputada de Lingua da Deputación de Pontevedra, María Ortega Iñarrea, e as coordinadoras, as académicas correspondentes Ana Boullón e Luz Méndez.

O programa desenvolveuse da seguinte maneira:

$10: 00 \mathrm{~h}$

- A denominación da disciplina / Anton Santamarina

- O que vale un nome. Sobre marcas, empresas e dominios en internet Benigno Fernández Salgado 
11:00 h Marcas galegas: tendencias e representacións

- Deleite, Bico de Xeado... Os recursos lingüísticos ao servizo das marcas comerciais / María Álvarez de la Granja

- As marcas e a súa relación coa paisaxe lingüística: a rotulación de Redondela / Sara Míguez

- As cabeceiras dos xornais galegos: unha viaxe pola historia / / Víctor F. Freixanes

- A etiqueta que viste o viño. Achega ao nome das adegas, viños e licores da D.O. Ribeiro /Raquel Rodríguez Parada

Modera: Antón Palacio

$16: 15 \mathrm{~h}$

- Nomes de bares e restaurantes: experiencia didáctica en Coia / / Celtia Rei Brandón

17:15 h Vender nomes propios. Mercado, marca, lingua

- Elena Ferro. Eferro. Zoqueira.

- Xosé González Martínez. Fundador do Foro E. Peinador de empresas pola normalización da lingua e impulsor da campaña de etiquetado en galego Con acento propio.

- Irene García e Raquel Boo. Ekinocio. Estudio de deseño e comunicación. Modera: Luz Méndez

O coordinador do Seminario de Onomástica, Antón Santamarina, analizou as alternativas propostas nas últimas décadas para a denominación desta disciplina, pero advertiu de que a mellor opción era falar de "onomástica comercial", como acontecía noutros idiomas: nom commercial, Haldname, brand name etc. Benigno Fernández Salgado investigou para a ocasión o universo emocional que rodea as marcas galegas e elaborou unha listaxe das máis queridas tendo en conta a opinión de medio cento de estudantes universitarios. Estudou ademais a súa actividade corporativa na Rede en relación coas linguas e os nomes dos dominios desas marcas e empresas destacadas. Profundou tamén no concepto de "Marca Galicia”.

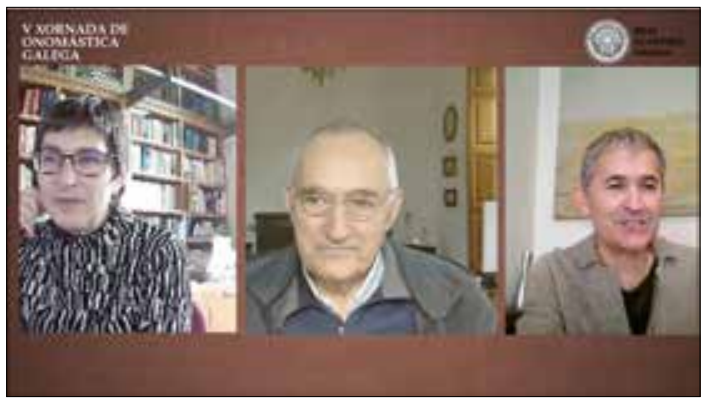

Ana Boullón, Antón Santamarina e Benigno Fernández durante a primeira sesión da Xornada. 
A profesora da USC María Álvarez de la Granja analizou os recursos lingüísticos ao servizo das marcas e dos nomes comerciais. A V Xornada de Onomástica Galega acolleu, ademais, a presentación dun traballo sobre a rotulación dos establecementos de Redondela realizado por Sara Míguez. O presidente da Real Academia Galega, Víctor F. Freixanes, retrocedeu no tempo nun relatorio sobre as primeiras cabeceiras de xornal en lingua galega, entre as que tamén é común o uso do topónimo e do xentilicio de noso. A filóloga Raquel Rodríguez Parada entrevistou case un cento de adegueiros e colleiteiros para estudar os nomes galegos das adegas e dos caldos inscritos na Denominación de Orixe Ribeiro (Ourense). O seu traballo permitiu comprobar que a maior parte dos nomes comerciais creados na comarca do Ribeiro fai uso da lingua galega.

A sesión da tarde abriuse coa intervención da profesora Celtia Rei Brandón, que expuxo unha experiencia didáctica sobre os nomes de bares e restaurantes nos barrios vigueses de Coia e Bouzas desenvolvida no IES Alexandre Bóveda de Vigo. Na última parte da xornada tivo lugar a mesa redonda que foi moderada por Luz Méndez en substitución de Gonzalo Navaza. A primeira en intervir foi Elena Ferro, filla e neta de zoqueiros, puxo de moda este calzado tradicional. A continuación interveu Xosé González Martínez, promotor da campaña de etiquetaxe en galego Con acento propio. As deseñadoras e creadoras de marcas do estudio Ekinocio Irene García e Raquel Boo foron as últimas en intervir.

Tras as intervencións dos participantes da mesa redonda, tivo lugar un pequeno coloquio no que atenderon as preguntas dos asistentes. Posteriormente, Luz Méndez presentou as conclusións e Víctor F. Freixanes, presidente da Real Academia Galega, clausurou a V Xornada de Onomástica Galega.

Os relatorios presentados na V Xornada de Onomástica Galega e a transcrición do coloquio posterior á mesa redonda están recollidos no volume Estudos de Onomástica Galega V. Os nomes comerciais.

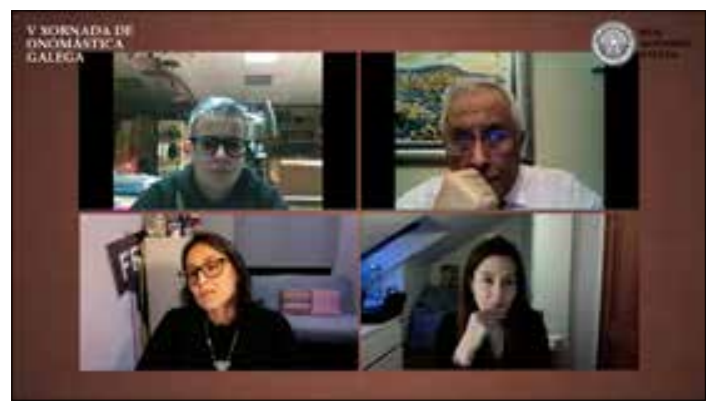

Os catro participantes da mesa de debate: Elena Ferro, Xosé González, Irene García e Raquel Boo.

Á dereita: cuberta de Estudos de Onomástica Galega V. Os nomes comerciais

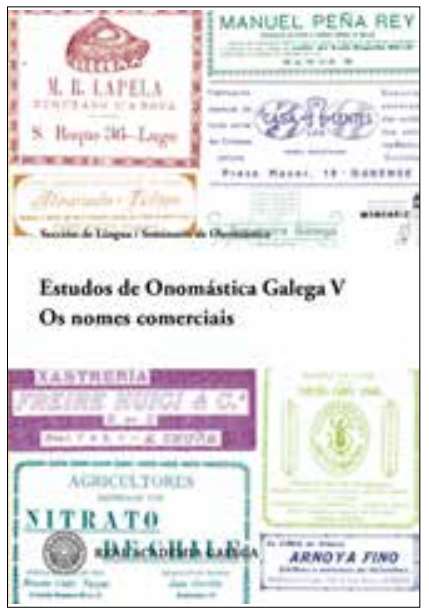




\section{OUTROS ACTOS E INFORMACIÓNS}

13 de xaneiro de 2020. O presidente da Real Academia Galega, Víctor F. Freixanes, participou na apertura dunha nova edición do programa 21 Días co galego, que neste ano chegou a dez centros de secundaria. A apertura da nova edición celebrouse no Colexio Fogar Santa Margarida e no IES Xelmírez I de Santiago de Compostela, institutos que traballaron cos alumnos e alumnas neste marco para promover que empreguen o galego dentro e, sobre todo, fóra do centro educativo. No colexio coruñés acompañou o director, Raúl Díaz Carballeira, Alfonso Sanmartín, membro do consello escolar, e o profesor Carlos Medrano. En Santiago de Compostela tomou a palabra canda o secretario xeral de Política Lingüística, Valentín García; o director xeral de Educación, Manuel Corredoira; o director do IES, Manuel Portas; a promotora e coordinadora do programa, Pilar Ponte, e a alumna de bacharelato Noela Rivas.

23 de xaneiro de 2020. O consello consultivo para o idioma frisón, DINGtiid, visitou a Real Academia Galega, onde foron recibidos polo presidente. Esta delegación visitaba neses días Galicia para coñecer a realidade do galego e dos distintos axentes institucionais implicados no seu estudo e promoción.

2 de marzo de 2020. O historiador Miguel Anxo Seixas Seoane presentou na Real Academia Galega o primeiro tomo da súa biografía Castelao. Construtor da nación. 1886-1930 (2019). O autor estivo acompañado na presentación polo presidente da RAG, Víctor F. Freixanes; Dolores Vilavedra, en representación da Editorial Galaxia; e o catedrático da USC e académico Ramón Villares, presidente do tribunal da tese na que se basea esta ambiciosa publicación.

3 de marzo de 2020. O presidente da RAG, Víctor F. Freixanes, e o coordinador do Seminario de Onomástica, Antón Santamarina, participaron no acto público de presentación da decisión adoptada por unanimidade pola corporación municipal do concello de Ribeira de asumir a forma lexítima do seu topónimo. $\mathrm{O}$ acto celebrouse no salón de plenos da casa consistorial, coa presenza de todos os grupos municipais.

9 de marzo de 2020. A RAG participa no Día do Galego no Bierzo. Nesta ocasión celebrouse tamén o centenario do autor berciano Ramón González-Alegre (1920-1968). A xornada arrincou en Vilafranca do Bierzo, a localidade onde naceu en 1695 frei Martín Sarmiento, e continuou en Cacabelos, onde se presentaron os III Premios Morales, convocatoria na que tamén colabora a Academia. O programa de actos, que contou co académico correspondente Héctor Silveiro en representación da RAG, incluíu ademais a presentación da versión galega da 
web do Consello Comarcal do Bierzo e rematou no Concello de Corullón dando a coñecer o primeiro volume dunha colección sobre o galego nesta bisbarra.

2 de abril de 2020. O presidente da Real Academia Galega participou na campaña promovida pola Academia Brasileira de Letras baixo o cancelo \#ABLemSuaCasa.

5 de xuño de 2020. O secretario da Real Academia Galega, Henrique Monteagudo, participou no programa Abralin ao Vivo, posto en marcha pola Associação Brasileira de Linguística. O coordinador do Seminario de Sociolingüística e secretario da Real Academia Galega repasou a situación do galego e das demais linguas minoritarias da Península Ibérica, os problemas que afrontan e a súa abordaxe.

9 de xuño de 2020. Co gallo da conmemoración do Día Internacional dos Arquivos, o arquivo da Real Academia Galega presentou as versións en galego do xeneral retirado Juan Beceiro Amado d'O Quixote e de distintas lendas irlandesas como "Oisín and Tír Na NÓg".

29 de xullo de 2020. O membro do equipo de traballo do Seminario de Sociolingüística da Real Academia Galega Gabino Vázquez Grandío participou no congreso da asociación Antropólogos Iberoamericanos en Rede. Interveu no panel "Escola, lingua, exclusión, diversidade e interculturalidade", que tamén moderou, cunha comunicación sobre os discursos e as actitudes cara ás linguas no sistema educativo de Galicia. O relatorio baseouse nunha análise a partir dun traballo de campo etnográfico desenvolvido en dous centros escolares de Lugo, nun colexio privado urbano e noutro público do rural.

15 de agosto de 2020. Os presidentes da Real Academia Galega e da Deputación da Coruña, Víctor F. Freixanes e Valentín González Formoso, asinaron o convenio a través do cal a entidade provincial apoia diversos proxectos que a RAG desenvolveu durante 2020.

30 de setembro de 2020. A Real Academia Galega, entidade participante do Premio Narrativa Breve Repsol, acolleu o acto en que se fixo público o ditame do xurado, que destacou a novela de Berta Dávila Illa decepción. O presidente da Real Academia Galega, Víctor F. Freixanes, participou na rolda de prensa en que se deu a coñecer a decisión do xurado xunto á directora da refinería de Repsol na Coruña, Natalia Barreiro; o director xeral da Editorial Galaxia, Francisco Castro; o presidente da Asociación de Escritoras e Escritores en Lingua Galega (AELG), Cesáreo Sánchez; o secretario xeral de Política Lingüística, Valentín García; e Anna R. Figueiredo, encargada de anunciar a resolución do xurado do que formou parte canda a académica correspondente Mercedes Queixas, Antón Lopo, Carlos González Lema e Armando Requeixo. 
1 de outubro de 2020. Presentación do concurso Olla a palabra do día, convocado desde o Portal das Palabras. A iniciativa, dirixida aos centros de Educación Infantil, Primaria e ESO, repartiu oito premios entre os traballos do alumnado que lles puxo imaxes aos termos da sección Palabra do Día durante o mes de outono. Cada traballo debía centrarse nun dos temas semanais propostos do 5 de outubro ao 1 de novembro, que eran, por esta orde, a celebración do Día da Nena; a vida e a obra do protagonista do Día das Letras Galegas 2020, Ricardo Carballo Calero; o Samaín e mais o coidado do medio natural. A convocatoria púxose en marcha coa colaboración do colectivo docente Galiza Visual, que promove esta ferramenta didáctica nas aulas de todos os niveis.

6 de outubro de 2020. Encontro institucional entre o presidente da Real Academia Galega, Víctor F. Freixanes, e a alcaldesa da Coruña, Inés Rey, no Pazo Municipal da Coruña. Na xuntanza abordaron a celebración en 2021 do centenario do pasamento de Emilia Pardo Bazán, acompañados da académica Marilar Aleixandre, coordinadora das actividades do centenario por parte da RAG.

9 de novembro de 2020. O presidente da Academia, Víctor F. Freixanes, e o titular da Xunta de Galicia, Alberto Núñez Feijóo mantiveron unha xuntanza en San Caetano na que abordaron, entre outros temas, a solicitude feita desde a Real Academia Galega para que a biblioteca de Emilia Pardo Bazán fose declarada ben de interese cultural (BIC).

12 de novembro de 2020. O presidente da Academia, Víctor F. Freixanes; o coordinador do Seminario de Terminoloxía, o académico Manuel González; e o director de Cultura do Concello da Coruña, Rómulo Sanjurjo, presentaron a proposta normalizada e oficial dos nomes das oitenta e oito constelacións recoñecidas pola Unión Astronómica Internacional nun acto celebrado na Casa das Ciencias, que concluíu ollando a recreación do ceo do planetario con Martin Pawley como guía.

21 de novembro de 2020. Presentación na sede da Real Academia Galega, da resolución da Dirección Xeral do Patrimonio Cultural pola que se incoa o procedemento para declarar ben de interese cultural a biblioteca de Emilia Pardo Bazán. No acto estiveron presentes o presidente da Real Academia Galega, Víctor F. Freixanes; o conselleiro de Cultura, Román Rodríguez; e a académica Marilar Aleixandre. Esta resolución publicouse no Diario Oficial de Galicia o 25 de novembro.

2 de decembro de 2020. Presentación do Congreso Internacional "Emilia Pardo Bazán, 100 anos despois", que se celebrará en outono de 2021 na sede da RAG e da Casa-Museo Emilia Pardo Bazán. 
O 15 de decembro de 2020, a Real Academia Galega e a Universidade de Santiago de Compostela presentaron o proxecto audiovisual Novas voces para a lingua, que a Real Academia Galega e a Facultade de Ciencias da Comunicación promoven para conectar a mocidade co idioma. No acto, conducido polo presidente da Real Academia Galega, Víctor F. Freixanes, estiveron presentes Ana Isabel Rodríguez, Gaspar Broullón e Martín Vaz, profesores da Facultade de Ciencias da Comunicación da USC, os tres autores da serie, Paula Quiroga (directora), Lois Alcayde (guionista) e Meritxell Álvarez (produtora), o decano do centro, Xosé Ramón Pousa e varios participantes da serie.

22 de decembro de 2020. Celebración do pleno da Real Academia Galega no que se decidiu dedicar o Día das Letras Galegas de 2021 a Xela Arias, unha das voces máis destacadas da poesía galega contemporánea, editora e tradutora de milleiros de páxinas de clásicos universais ao galego.

25 de decembro de 2020. Nós foi proclamada Palabra do Ano 2020 polas persoas que participaron na elección popular promovida polo Portal das Palabras. O certame A palabra do ano desenvolveuse en dúas fases: unha de recollida de propostas e outra de votación entre seis finalistas, nas que participaron máis de cinco mil quiñentas persoas.

31 de decembro de 2020. O Dicionario da Real Academia Galega superou en 2020 as 38.500 .000 buscas, máis de 105.000 ao día de media. As consultas medraron case un $50 \%$ con respecto ao ano 2019 , cando xa se producira un incremento por riba do $18 \%$ con respecto ao 2018 e se chegara ás preto de 26.0000 .000 procuras. A entrada en vigor do primeiro estado de alarma por mor da pandemia marcou un punto de inflexión e rexistrou a marca histórica de buscas no mes de maio de 2020, que pechou con máis de 4.800.000.

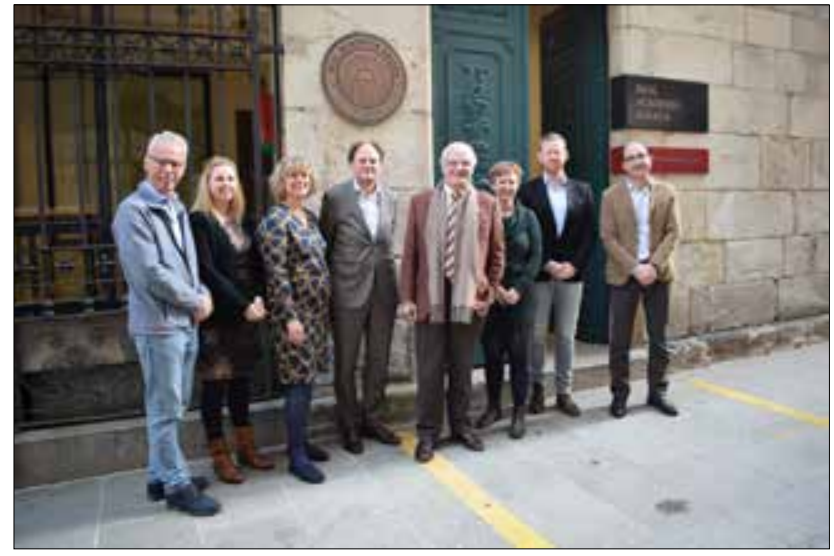

Visita do consello consultivo para o idioma frisón. 23 de xaneiro de 2020. 
Presentación da proposta oficial dos nomes das 88 constelacións recoñecidas pola Unión Astronómica Internacional. 12 de novembro de 2020.

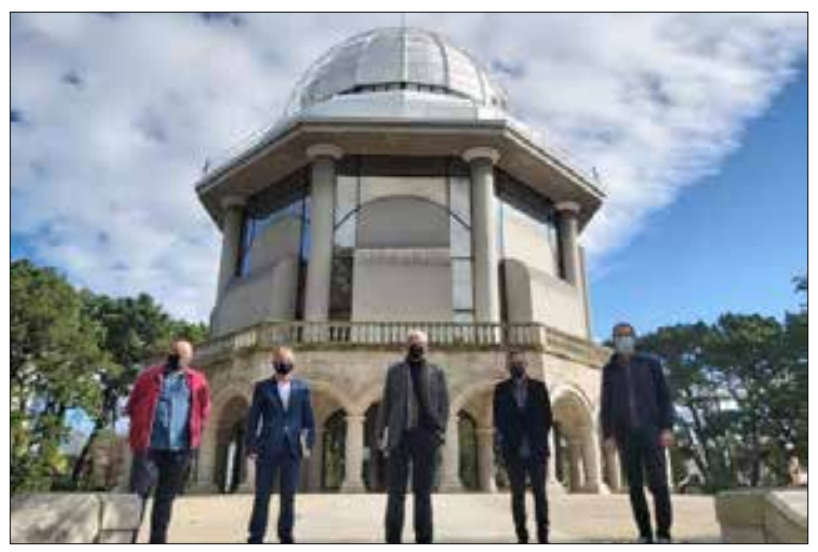

A biblioteca de Emilia Pardo Bazán é declarada ben de interese cultural.

21 de novembro de 2020.

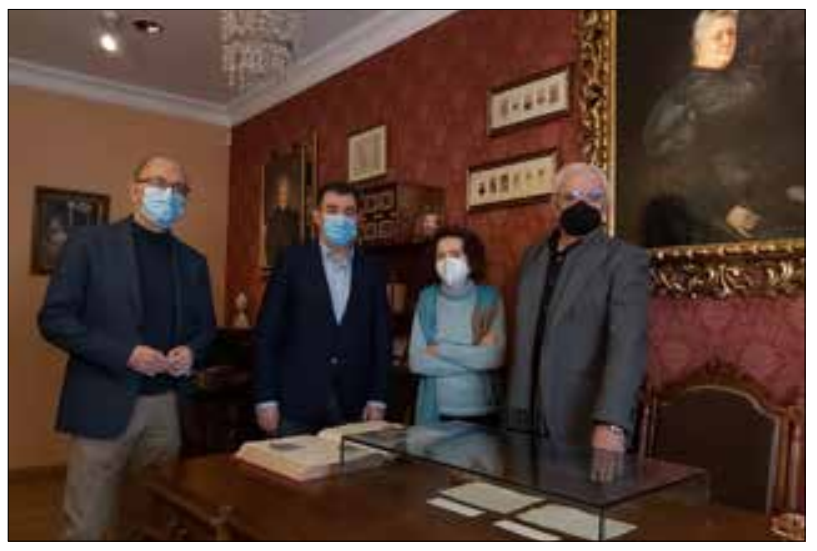

Presentación do proxecto audiovisual Novas voces para a lingua. 15 de decembro de 2020.

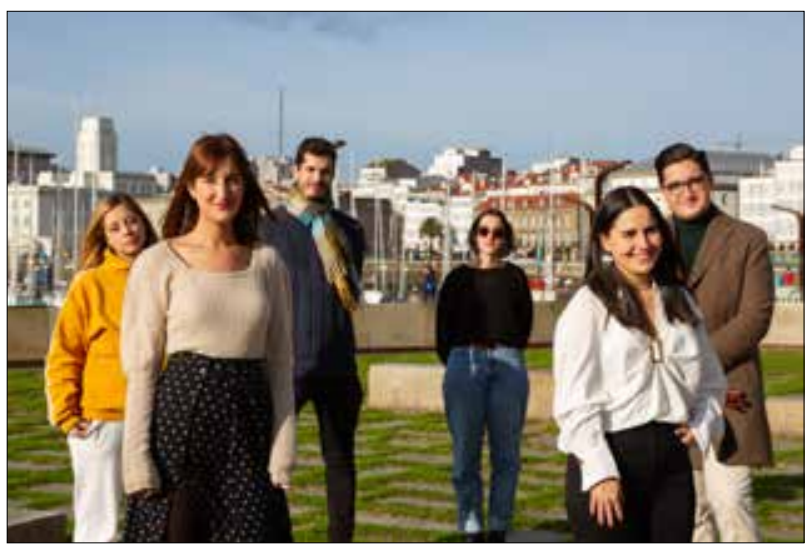




\section{ACTIVIDADES DA CASA-MUSEO EMILIA PARDO BAZÁN}

Durante o ano 2020 e debido á situación sanitaria provocada pola pandemia da covid-19, a Casa-Museo Emilia Pardo Bazán permaneceu pechada dende o 16 de marzo ata o 1 de xuño de 2020. A partir desta data, as persoas que desexaron consultar os fondos de calquera destes dous servizos foron atendidas con cita previa.

Para dar resposta á situación deseñouse un protocolo de visitas, seguindo os documentos pertinentes publicados pola Xunta de Galicia e o Ministerio de Cultura. Aínda que a cifra de visitantes é sensiblemente menor que outros anos, a calidade da visita medrou enormemente. O número de visitantes da casa Museo en 2020 foi 2148 .

\section{AcTIVIDADES REALIZADAS EN 2020}

\section{Musealización:}

O 9 de maio de 2020 comezaron os traballos da campaña de reintegración das pezas que unicamente estaban protexidas por actuacións de conservación preventiva. Foron seleccionadas e retiradas as pezas máis necesitadas de desinsectación.

A partir do 12 de maio recepcionáronse as pezas desde os talleres de desinsectación e de restauración e comezou a montaxe do espazo expositivo, ademais de levar a cabo traballos técnicos co equipo de restauradoras na hidratación de madeiras, tinguido de faltas pequenas e selección e montaxe de copias fotográfi-

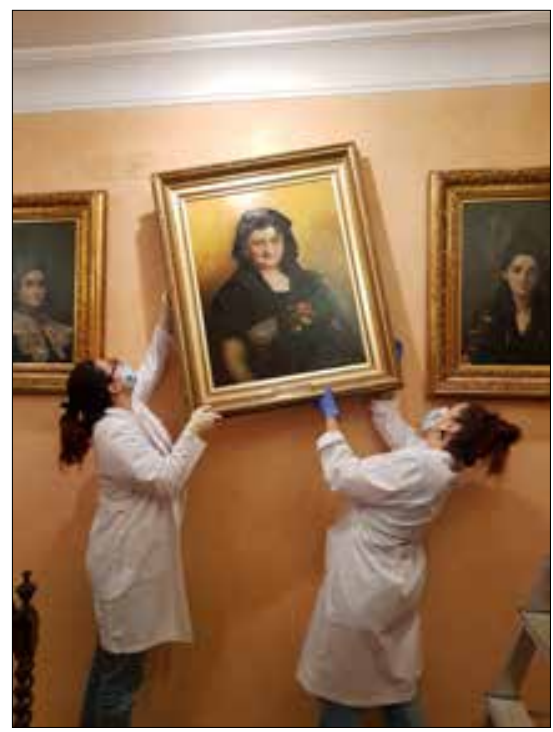
cas que tiñan perdida a prestancia desde a anterior revisión museográfica.

Ademais, aproveitáronse os meses durante os que a Casa-Museo permaneceu pechada ao público para realizar os seguintes traballos:

- Deseño e montaxe da exposición "Amizades", na sala IV.

- Actualización das cartelas do museo.

- Revisión e proposta de follas de información das salas. 


\section{Didácticas:}

A mellora e a actualización das didácticas empregadas no funcionamento da Casa-Museo foron outros dos traballos nos que se aproveitou o tempo durante o intervalo pandémico. Algúns destes traballos son os seguintes:

- Deseño dunha visita virtual para escolares de Primaria.

- Posta en marcha da unidade didáctica da visita autónoma para o alumnado de Secundaria.

- Elaboración dun proxecto de visita virtual, destinada ao alumnado da ESO, en colaboración co profesorado do IES de Sabón. Consistire nunha montaxe de imaxes da Casa en $360^{\circ}$ acompañada de locucións do alumnado sobre determinadas pezas.

- Deseño e redacción de varias unidades didácticas destinadas ao alumnado de Primaria:

Angulo Miró, P. (2020). Emilia Pardo Bazán. O despertar dunha escritora (1ํ, 2ำ e $3^{\circ}$ Educación Primaria). A Coruña: Casa-Museo Emilia Pardo Bazán. Cadernos do profesorado e do alumnado. http://doi.org//10.32766/rag.375

Angulo Miró, P. (2020). Emilia Pardo Bazán. De nena lectora a escritora

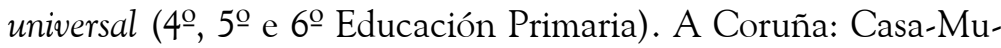
seo Emilia Pardo Bazán. Cadernos do profesorado e do alumnado. http://doi.org//10.32766/rag.374

Angulo Miró, P. (2020). A hora dos contos (Educación Primaria). A Coruña: Casa-Museo Emilia Pardo Bazán. Cadernos do profesorado e do alumnado. http://doi.org//10.32766/rag.376
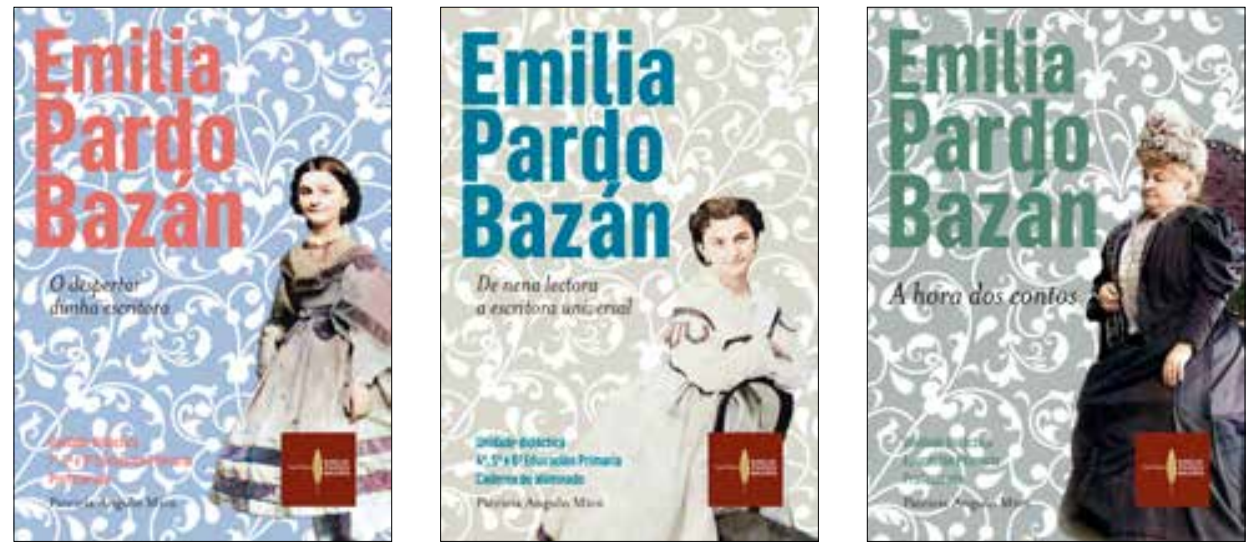


\section{Difusión:}

\section{Ilustrando contos de Emilia Pardo Bazán}

Co obxectivo de promover o coñecemento da figura e da obra da escritora entre o alumnado de 4을 de Educación Secundaria, convocouse o Certame de Ilustración 2020. As bases foron publicadas coincidindo co Día da Ilustración, o 30 de xaneiro. Esta convocatoria adiouse debido á pandemia da covid-19.

\section{¿Quién teme a Emilia Pardo Bazán?}

O día 1 de xullo levouse a cabo desde a Universidad Rey Juan Carlos o curso online ¿Quién teme a Emilia Pardo Bazán? Este monográfico, que derivou nun curso virtual por consecuencia da covid-19, organizouse, dirixiuse e presentouse desde a Casa-Museo por Xulia Santiso.

Conferencia: "Mais aló das tarefas museolóxicas. Coordinación para a catalogación da biblioteca das Torres de Meirás"

Apertura do curso universitario do Mestrado en Estudos Avanzados en Museos, Arquivos e Bibliotecas (Universidade da Coruña, campus de Ferrol). Este é o único mestrado universitario no panorama español que une as especialidades de Museos, Bibliotecas e Arquivos históricos.

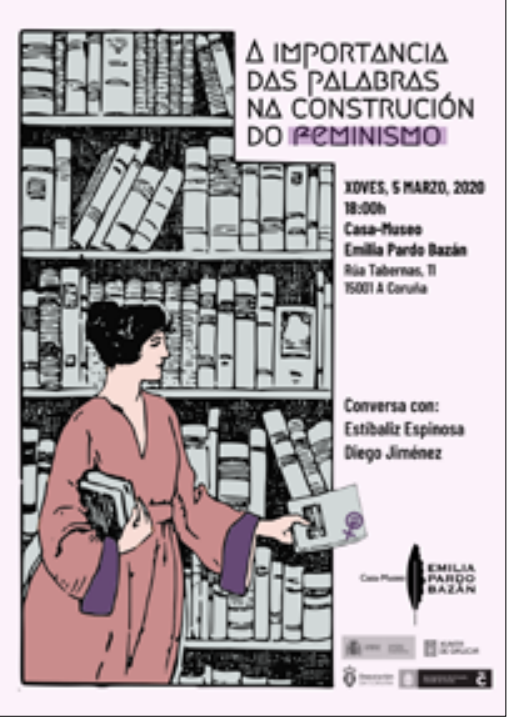

A importancia das palabras na construción do feminismo

Co gallo da celebración do 8 de marzo, o 5 dese mes reuníronse na Casa-Museo a escritora Estíbaliz Espinosa e o comunicador Diego Jiménez para reflexionar sobre a igualdade entre mulleres e homes.

\section{Día Internacional dos Museos}

No Día Internacional dos Museos (18 de maio) debido á imposibilidade de realizar actividades presenciais para festexar a data, a Casa-Museo Emilia Pardo Bazán colgou na súa páxina web unha visita virtual. 


\section{IN MEMORIAM}

\section{XOSÉ LÓPEZ CALO}

Xosé López Calo naceu en 1922 na parroquia de Nebra, en Porto do Son, e ingresou na Compañía de Xesús en 1942. Licenciado en Filosofía e Letras pola Universidade de Comillas e en Teoloxía pola de Granada, era doutor en Filosofía e Letras pola Universidade de Santiago de Compostela (USC) e en Musicoloxía polo Pontificio Instituto de Música Sacra de Roma, onde se doutorou en 1962 cunha tese sobre a música na catedral de Granada no

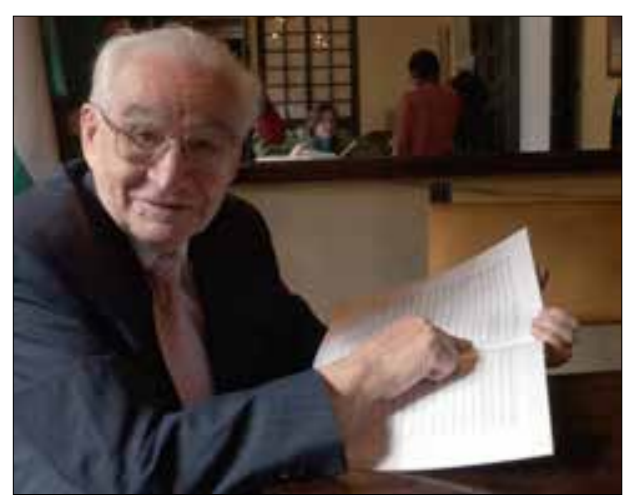

Foto: Juan Ferreras. EFE século XVI. Dende 1973 era profesor da USC, onde se xubilou como catedrático de Historia da Música. Gran defensor das músicas tradicionais, realizou numerosos catálogos e estudos dos arquivos das principais catedrais de España, entre elas a de Santiago de Compostela, con contribucións esenciais arredor do Pórtico da Gloria e do Códice Calixtino. Xosé Calo finou en Salamanca o 10 de maio de 2020.

O legado do académico inclúe ducias de libros de musicoloxía, artigos e entradas en enciclopedias e nos principais dicionarios de música do mundo, entre eles o alemán Die Musik in Geschichte und Gegenwart e The New Grove Dictionary of Music and Musicians, ao que achegou máis de duascentas voces sobre música e autores españois. Ademais de pertencer á RAG dende finais dos anos 60, era membro de numerosas sociedades e academias: foi socio fundador das sociedades nacionais de musicoloxía de España e Italia, académico de honra da Real Academia Galega de Belas Artes e correspondente da Real Academia de Belas Artes de San Fernando e das de Granada, Sevilla, Segovia e Valladolid. Entre outros recoñecementos, en 1989 recibiu a Medalla de Ouro ao Mérito das Belas Artes e en 2002, o Premio das Letras e das Artes de Galicia. 


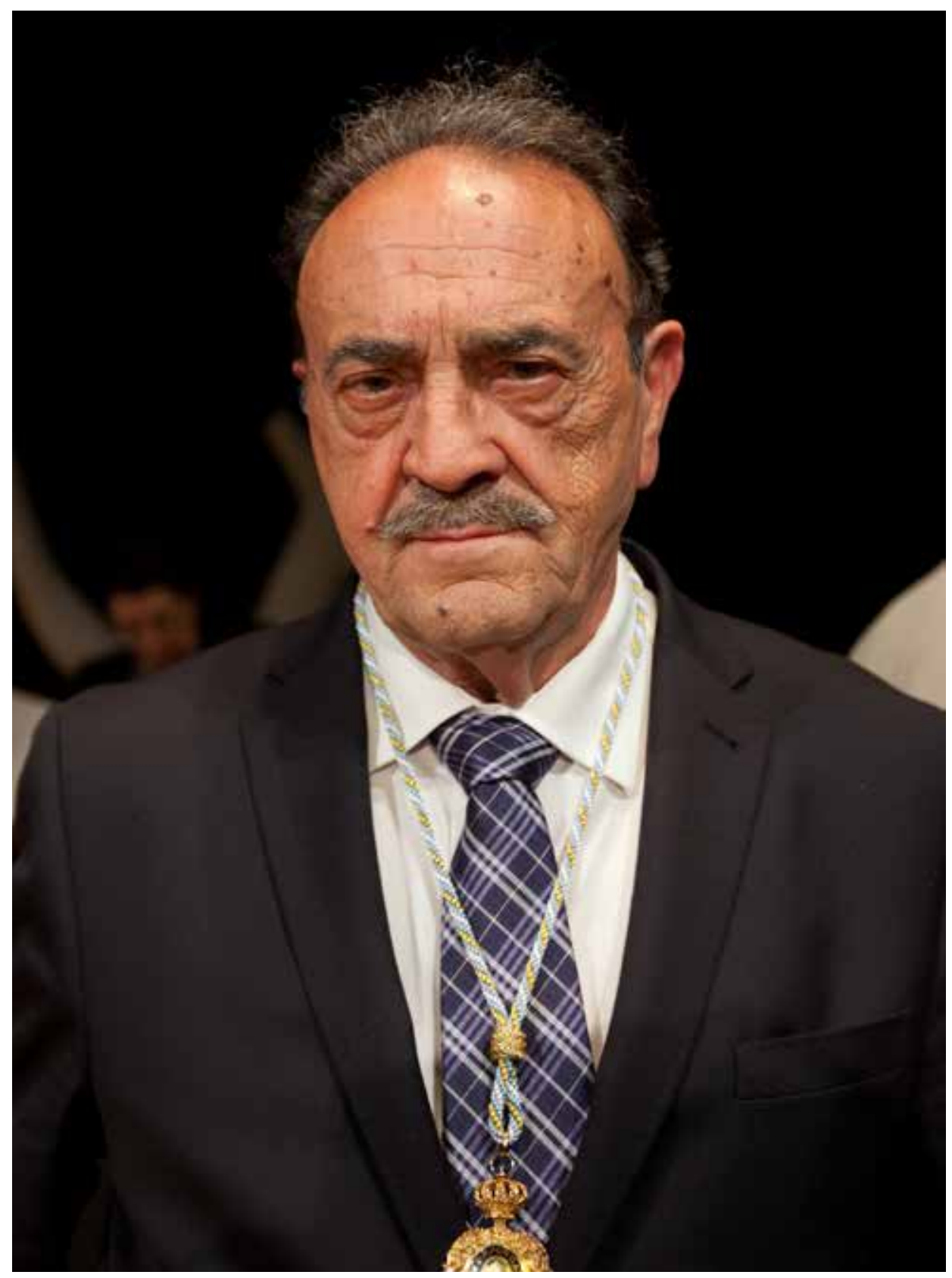

Xosé Luís Franco Grande / Xosé Castro 


\title{
XOSÉ LUÍS FRANCO GRANDE (1936 - 2020)
}

\author{
Ramón Lorenzo
}

O día 31 de marzo de 2020 morreu en Vigo o académico Xosé Luís Franco Grande, unha das personalidades máis sobranceiras da cultura galega e para min un amigo incondicional desde os anos de estudantes en Compostela. Xosé Luís naceu en Tebra (Tomiño) o 17 de febreiro de 1936 e alí pasou toda a súa infancia e primeira xuventude, un lugar que o marcou para sempre e que lle serviu de refuxio. El tivo a sorte de que seus pais eran mestres naquel lugar e de que o educaron con esmero, inculcándolle só valores positivos e facendo que se criase nun ambiente no que dominaba a cultura. Rodeado de libros, foi á escola primaria no propio Tebra (1942-1947) e ós dez anos comezou o bacharelato por libre. Eran seus pais os que o axudaban cos estudos e para o latín botaba unha man o cura da parroquia. Así pasou os tres primeiros anos (1947-1950) e xa en cuarto foi facer o resto do bacharelato ó Instituto Santa Irene de Vigo (1950-1954). Franco Grande xa desde pequeno tivo querenza pola literatura e aínda cando estaba en Tebra xa comezou a escribir textos, afección que aumentou ó entrar no Instituto, onde se dedicou a escribir na revista que publicaba o centro. Desde entón non deixou de deleitarnos con toda clase de escritos ata a súa morte.

Rematado o bacharelato, trasladouse a Santiago en 1954 para estudar Filosofía e Letras, pero o ambiente que se respiraba na facultade non era do seu agrado, sobre todo debido ó absurdo profesor de lingua e literatura española que era moi arbitrario e co que tivo un enfrontamento. Iso levouno a deixar estes estudos e no curso seguinte (1955-1956) decidiuse por comezar a carreira de Dereito que rematou brillantemente en 1960.

Os anos de Santiago foron moi ricos en experiencias e Franco Grande foi un dos grandes protagonistas daquela xeración de estudantes. Aínda agora escribindo venme á lembranza a súa figura baril, a seguridade con que argumentaba, o dominio da literatura que posuía e tamén os esforzos que facía para dominar o seu nerviosismo. Alí coincidiu con Bernardino Graña, Gustavo Docampo, Ramón Lugrís, Beiras, Méndez Ferrín, Mourullo, López Nogueira e moitos outros e entrou en 
contacto con Otero Pedrayo, Ramón Piñeiro, García Sabell, Bouza Brey, Alonso Montero, Río Barja, Borobó e tantos máis.

Participou nas Festas Minervais, nas que conseguiu ser premiado numerosas veces e en cinco ocasións acadou o primeiro premio de poesía, e tomou parte no ciclo de conferencias que organizamos no Círculo Mercantil falando sobre Manuel Antonio. Fóra dos estudos tiña tempo para asistir ós faladoiros do Café Español arredor de Otero Pedrayo e anos despois ós que celebraba con outros compañeiros no Bar Viño. E sempre quedaba tempo para a troula e os paseos pola Alameda ou polos arredores da cidade. Era a época da xeración que Borobó quixo chamar "Xeración de La Noche", porque moitos escribiamos neste xornal. Foron os tempos en que se embebeu de galeguismo e de europeísmo, en que acumulou lecturas e sabedoría, tamén filosófica, entusiasmado con algúns filósofos como Sartre e especialmente co seu admirado Søren Kierkegaard. Toda esa época de 1954 a 1960 está marabillosamente descrita no seu libro Os Anos escuros. I. A resistencia cultural da xeración da noite (1954-60) (Edicións Xerais de Galicia, 1985), máis tarde ampliado en Os Anos escuros. A resistencia cultural dunha xeración (Galaxia, 2004). Anos "escuros", mais tamén luminosos, porque neses anos de estudante atopou a amizade de mestres e compañeiros que, con máis altos ca baixos, durou toda a vida. El mesmo deixou dito: "Debo todo na miña vida ós compañeiros de xeración e ós galeguistas que na década dos cincuenta retomaron a loita pola dignidade nacional de Galicia".

Acabada a carreira en 1960 marchou á Coruña para traballar como pasante co avogado e académico Sebastián Martínez Risco, co que aprendeu realmente o oficio de xurista. Xa ben formado, trasladouse a Vigo, onde exerceu como avogado, traballou con Xaime Isla Couto e entrou como asesor xurídico da Caixa de Aforros de Vigo, despois Caixanova, ata a súa xubilación en 2001. A partir do seu estabelecemento en Vigo, onde casou e tivo dúas fillas, permaneceu nesta cidade ata a súa morte, pero sempre coa constante presenza da súa Tebra natal.

Como escritor podemos destacar varios aspectos da súa extensa produción. Aínda que, como xa dixen, de estudante se deu a coñecer como poeta nas Festas Minervais e en 1955 o Centro Galego de Buenos Aires lle concedeu o premio Eduardo Pondal ó seu poemario Brétemas do vieiro, que deixou inédito, tardou bastantes anos en publicar o seu primeiro libro de poesía. Foi en 1967, Entre o si e o non, publicado pola Editorial Galaxia (na colección Salnés no 23), libro que conseguiu o Premio Nacional de Poesía Rosalía de Castro en 1967, se ben é certo que por insistencia de Fernández del Riego xa dera a coñecer "13 poemas" (Grial 5, 1964, 333-344), cun limiar no que di que o libro "segue facéndose moi de vagar, pero sen descanso. Cada ano, aínda que case non me decate, medra un pouco e bota un anelo máis, como as carballeiras fondamente arraizadas alá no val de 
Tebra, onde tamén están as miñas raíces" (p. 333). Trátase dun libro dividido en catro partes ("Adro e altar", "Cancións de amor e soedade", "Poemas do tempo perdido" e "Outros poemas", nesta última parte con poemas de 1953 a 1956). Nunha época en que dominaba a poesía social, Franco Grande publica uns poemas totalmente diferentes, unha poesía existencial, á procura de si mesmo, chea de amor e sufrimento, de pesimismo e con Tebra sempre presente. Unha poesía que non todos eran capaces de comprender, como lle pasou a Ramón Piñeiro, a quen lle pediu un prólogo para o libro nunha carta do 27 de abril de 1966, prólogo que non fixo, aínda que anos despois (carta de 10 de setembro de 1987) soubo comprender a gran categoría dos poemas e fixo un vasto eloxio deles.

O libro foi reeditado en 2002 pola Voz de Galicia dentro da colección Biblioteca Galega e Vicente Araguas preparou unha edición na que fixo un profundo estudo da súa poesía e que saíu en 1993 en Edicións Xerais de Galicia. Pero xa antes disto o propio Franco Grande incluíu o libro no seu poemario Herdo de memoria e tempo, publicado por Edicións Xerais de Galicia en 1987. Nel, alén de Entre o sí e o non, presenta Tempo á espreita (pp. 81-161). Tamén nesta ocasión divide o libro en catro partes. A primeira ("Monumento funerario para a túa ausencia") é unha sentida elexía á morte do pai. A segunda ("Humus") son poemas concentrados na visión de Tebra e da terra. A terceira ("Smog") refírense ó mundo da cidade, chea de aburrimento. Finalmente a cuarta ("Ocasións") recolle poemas dedicados a persoas ou personaxes literarios, ás execucións de Tchiki e Otaegui, Baena, García Sanz e Sánchez Bravo, e dous que lles fixo ás súas fillas Rosalía e Navia: Rosalía chamada así por amor a unha tía e a Rosalía de Castro, a quen lera xa de pequeno e a quen tivo sempre como referente, xuntamente con Rilke; e Navia por instigación de Bouza Brey, por referencia á deusa prerromana da auga, das fontes e dos ríos. Na introdución quéixase da falta de tempo para escribir máis, pensa que facelo en certas circunstancias é un acto heroico, "pero que cómpre, se un quere seguir vivo" (p. 10) e acúsase de non telo visto antes con tanta claridade. Nunha ocasión escribiu "A miña poesía non se explica sen Tebra" (Nordés 4, 1976, 29-31) e neste lugar, con total pesimismo, escribe a introdución vendo o cambio profundo na sociedade galega para mal, aínda que a esperanza é o único que nos sostén. Nestes poemas, e desde sempre, o poeta está á procura da identidade (Pozo 1988), do eu propio, mentres contempla a fuxida do tempo.

Na páxina web da RAG dinos: "A miña profesión impediume deica agora face-la obra literaria que eu quixera. Pode que, agora xubilado, escriba aínda unha ducia de libros". Non chegou a tantos, pero seguiu facendo poesía e así en 2015 apareceu Xoguetes do tempo, publicado por Galaxia, do que dera a coñecer algúns poemas en Grial (207, 2015, 93-95), e en 2017 deleitounos coa primorosa edición do Libro das abandonadas, publicado en Santiago por Teófilo Edicións. En Xoguetes 
do tempo presenta tres partes, tituladas "Na moega de tempo", "Xanela aberta" e "Lentura", cun poema introdutorio (p. 9) que nos indica a materia que trata unha boa parte do libro:

\section{Como as follas polo outono acaneadas polo vento sen paraxe andamos porque xoguetes somos do tempo.}

Velaí o tempus fugit clásico e por iso na primeira parte está sempre presente o paso do tempo, a chegada da morte, dos "derradeiros chanzos" da vida. A segunda volve ó transcorrer do tempo na cidade nun ambiente pesimista e na terceira atopamos de novo a volta á terra onde se criou, á descrición da paisaxe no val de Tebra, xunto á insistencia no canto á patria (López-Casanova 2016; Losada 2016; Lamas 2016). No Libro das abandonadas cambia de temática e presenta unha serie de poemas que lle andaban dando voltas pola cabeza e que escribiu en poucos días, un pouco lembrando a Rosalía e a Rilke, que trataron o tema. Divide o libro en tres partes. A primeira, "A abandonada filla do mar", canta á nena abandonada nos primeiros días da súa infancia. A segunda refírese "ás abandonadas viúvas de vivos" e a terceira "ás amantes abandonadas". Como apéndice inclúe tres sonetos con tres inscricións para gravar nas campas de Gaspara Stampa, da monxa portuguesa Mariana Alcoforado -das que falou Rilke-, e na de Marylin Monroe. En total son 31 poemas de homenaxe ás mulleres que sufriron o abandono dos pais, dos maridos ou dos amantes, con versos de excelente feitío e de gran sentimento.

Como colofón ós libros de poesía hai que indicar que algúns dos poemas contidos neles apareceron antes en revistas ou en antoloxías, como en Nordés (1, 1975; 2-3, 1975; 4, 1976; II data: 1, 1980; 3, 1981), Dorna (9, 1985; 10, 1986; 28, 2002), Escritos (Lugo, marzo 1960), Destino (1324, decembro 1962), Claraboya (16/17, 1967), Irmandade (Ano 3, 26, 1968) etc. e, entre outras, nas antoloxías de Basilio Losada, Poetas gallegos de postguerra (Llibres de Sinera, 1971, 166-171); Francisco Fernández del Riego, Antoloxía de poesía galega. Do posmodernismo aos novos (Galaxia, 1980, 441-451); Manuel Fernández Rodríguez, Poemas pola memoria (1936-2006). Ano da memoria 2006 (Xunta de Galicia, 2006, 178-180); Antonio Raúl de Toro Santos, Breogán's lighthouse. An anthology of Galician literature (Francis Boutle, 2010, 434-436); Vicente Araguas, La lluvia en el mar. Una antología de poesía gallega (Pigmalion, 2018); e tamén na Antoloxía da poesía galega actual (Edicións do Castro, 1978, 193-219) e en Poetas e narradores nas súas voces (Consello da Cultura Galega, I, 2001, 32-38). Ademais, publicou un artigo cunha "Panorámica de la poesía gallega actual" (Insula 152-153, 1959, 
p. 15), outro sobre a "Presenza da cultura galega no exterior" (Tempo exterior 17, 2008, 91-97) e contestoulle ó discurso de ingreso de Camilo Suárez-Llanos na Academia falando Sobre a literatura galega. Un achegamento subxectivo (Real Academia Galega, 2002).

Curiosamente, aínda que Franco Grande sempre se caracterizou pola súa faceta de poeta, o primeiro libro que publicou foi unha obra de teatro, co título Vieiro choído. Peza dramática en tres tempos e seis cadros (Galaxia, 1957), que iniciaba a colección Illa Nova e que Galaxia reeditou en 2018 como homenaxe ó escritor (Fontoira 1973, pp. 360-365). É unha obra complexa, que non todos comprenderon e da que o propio autor renegou, como lle di a Ramón Piñeiro (carta de 5 de xaneiro de 1960), ó mesmo tempo que lle anuncia que estivera traballando intensamente e que xa rematara outra peza co título A volta de Ulises, que nunca chegou a publicar.

Outra faceta importante foi a de dinamizador cultural desde a época de estudante. A el e a Beiras se debe a tradución do famoso "We shall overcome", que cantaba Joan Baez e que como "Venceremos nós" se converteu no himno das loitas estudantís do 1968. Tamén traduciron os dous a Antígona de Anouilh, con grande éxito na lectura escenificada que se fixo na sala de concertos do Hostal en maio 1959 e na representación levada a cabo en marzo de 1960 en Fonseca, e Non haberá guerra de Troia, de Jean Giraudoux (os textos foron publicados en Grial 17, 1967, pp. 319-353, e 23, 1969, pp. 37-77). Anos máis tarde traduciu para a Escola Dramática Galega A Tuta e a Ramoneta, de Llorenç Villalonga (1984). As súas inquietudes están moi ben expresadas na "Carta a un mozo galego de hoxe" (Grial 20, 1968, 217-222), dedicada a "Guillermo Roxo, trovador galego", con profundas reflexións e recomendacións sobre as tarefas que podía facer. En Vigo participou activamente na emisión Raíz e tempo, a primeira emisión radiofónica en lingua galega, que se radiaba semanalmente en La Voz de Vigo e que dirixiu durante algún tempo (artigos en Grial 13, 1966, 369-374; 16, 1967, 217-222; 201, 2014, 110-117).

Participou tamén na fundación da Asociación Cultural de Vigo e colaborou estreitamente con Galaxia e coa revista Grial. Froito diso son as numerosas recensións que escribiu sobre diferentes libros (Grial 3, 1964, 125-128; 18, 496498 e 505-508; 19, 1968, 109-110, 116-117; 20, 1968, 244-245; 21, 1968, 366$368 ; 31,1971,120-121 ; 34,504-506 ; 37,1972,371-372 ; 41,1973,376-377$; 42, 1973, 503-504, 507-508), así como o limiar a Voce na néboa de Méndez Ferrín (1957). Esa colaboración fixo que Fernández del Riego pensase nel para a redacción dun novo dicionario, porque o consideraba unha persoa moi disciplinada. El, que xa dera a coñecer moitas palabras de Tebra no Apéndice ó Diccionario enclopédico gallego-castellano de Eladio Rodríguez (vol. III, 1961), púxose á tarefa 
dilixentemente. Así apareceu en Galaxia o Diccionario galego-castelán e vocabulario castelán-galego (1968), moi aumentado na 2ª edición (1972), que serviu de guía durante moitos anos (a 8 ed. é de 1983) ós que traballaban coa lingua galega, xunto ó Vocabulario galego-castelán (1972). Tebra está no dicionario e nos poemas, pero tamén se lembrou dela nun estudo etnográfico sobre a "A festa das sete vacas, en Tebra: iReminiscencia dun vello culto xermánico?" (Grial 39, 1973, 10-34).

A súa capacidade de traballo levouno a facer unha edición exemplar da Obra completa de Manuel Leiras Pulpeiro (Galaxia, 1970), cun estudo e anotacións, e unha edición de Cara a Times Square do seu amigo Camilo Gonsar (Edicións Xerais de Galicia, 1989), a quen lembra nunha necrolóxica no BRAG (370, 2009, 331-332). Ademais fixo crítica literaria e valoracións persoais de escritores en diversos artigos, como en "Arredor dun poema de Rosalía" (Grial 21, 1968, 326333), "Castelao ou a claridade" (Río 6, 1999, 6-7), "Díaz Castro, nesta hora" (Grial 6, 1964, 512-518), onde aproveita para escribir sobre a poesía en xeral, con ideas críticas e orixinais, "A eficacia expresiva de Díaz Castro" (en Homenaxe a X. M. Díaz Castro, Asociación Cultural Xermolos, 1987, 48-56), "Outra lectura de X. Ma Díaz Castro" (en Nimbos: cáliz fervendo!, edición de Luís Cochón, Santiago de Compostela, Xunta de Galicia, Cadernos Ramón Piñeiro XXIX, 2014, 139-147), "Introducción a Alvaro Cunqueiro" (Grial 42, 1973, 403-416), "Castelao de lonxe" (Grial 47, 1975, 109-110), "Un clásico anovador" (sobre Cara a Times Square, en Crítica e autores. Artigos e entrevistas publicados en La Voz de Galicia, 2002, 297-298) ou "Cómpre volver a Pondal" (BRAG 376, 2015, 415-421). Tamén se ocupou de García Lorca con José Landeira Yrago en Ínsula (339, 1975, 3) e en "Cronología gallega de Federico García Lorca y datos sincrónicos" (Grial 45, 1974, 280-307).

Non remata aquí o inmenso labor de Franco Grande. Desde moi novo comezou a escribir artigos na prensa, pois, como el mesmo deixou escrito na páxina web da Academia, "procurei sempre escribir na prensa na medida que mo permitiron as miñas ocupacións, como maneira de seguir mantendo relación cos lectores e dicirlles que un aínda está vivo". Fíxoo sistematicamente e son moreas os artigos que apareceron en diversos medios, como La Noche, A Nosa Terra, Tempos novos ou La Voz de Galicia. Home con ideas claras e defensor da identidade galega, escribiu sobre a lingua, a política galega, os partidos políticos, Europa e a política internacional, sempre cun criterio propio e cunha visión nítida da realidade, unhas veces con optimismo e outras con pesimismo e sempre con sinceridade e firmeza. Abonda con ler os 682 artigos que escribiu na Voz de Galicia desde o 17 de marzo de 2002 sobre os temas máis variados, con especial insistencia na política española e na internacional, sen esquecer nunca a cultura e a política galegas, con apreciacións lúcidas e acertadas, ou os numerosos artigos que apa- 
receron en Tempos novos, con títulos nos últimos anos como "Malia a actitude sumisa de moitos, Galicia aínda é posible" $(32,2000)$, "Tortura na guerra contra o terror. Intereses militaristas e económicos" $(101,2005)$, "Uns soben, outros baixan e algúns gañan" sobre a política galega $(185,2012)$, "Tres eixes dunha política de esquerdas" sobre o Bloque, PSOE e as Mareas (224, 2016), "Unha democracia minguante" $(250,2018)$, "Volve a España Negra" coa política do PP $(251,2018)$, "Por un patriotismo intelixente" $(255,2018)$, "Estado de dereito ou república bananeira" $(260,2019)$, "Fanatismos da dereita" sobre a dereita española con Casado, Rivera e Abascal $(261,2019)$, "Os nacional-populismos de ultradereita, ao asalto de Europa" $(265,2019)$, "Unha solución federal á vista?" (265, 2019), "Urxencias para o 2020" sobre Vox e a política en Cataluña e Galicia (272, 2020), "Tempos novos, maneiras novas" sobre a nova política co PSOE en Madrid $(273,2020)$ etc. E tamén en "África se busca a sí misma" (Grial 7, 1965, 96-103), "De ingleses cultos e galegos paifocos" (A Nosa Terra no especial, 2007), "Os independentistas galegos e o Estado" (en A semente da nación soñada. Homenaxe a X. L. Méndez Ferrín, 2008, 63-66) ou cando realizou unha análise moi crítica das eivas que presenta un libro de Piñeiro, en "Visión sobre a obra Da miña acordanza. Precisións a unhas memorias de Ramón Piñeiro" (Tempos novos 64, 2002), persoeiro a quen critica sincera e duramente en carta do 5 de agosto de 1981 pola política que levaba a cabo. Tampouco nas entrevistas disimulaba e respondía con precisión e valentía, criticando todo o que lle parecía que estaba mal feito, como se ve nas que lle concedeu a Xosé A. Neira Cruz (Tempos novos 24, 1999, 42-47), Begoña R. Sotelino (en Crítica e autores. Artigos e entrevistas publicados en La Voz de Galicia, 2002), Luís Villamor (Tempos novos 205, 2014, 34-39), "Galegos 19" (entrevista emitida na TVG 2 o 29 de xullo de 2015) ou a Héctor J. Porto (La Voz 29 de xaneiro de 2020).

Dentro do seu ideario político encádrase o seu libro Outra política para outros tempos (Galaxia, 2013), no que fala de Galicia e Europa, da importancia da cultura galega e da súa idea persistente de que se debería chegar a un federalismo das diferentes nacións. A súa condición de europeísta levouno tamén a colaborar co Instituto Galego de Análise e Documentación Internacional (IGADI) e a pertencer ó seu consello reitor. Home interesado pola política, aínda que nun principio se encadrou no Partido Socialista Galego, despois non quixo militar en ningún partido para poder exercer a crítica e ter independencia. Dínolo claramente na páxina web da Academia: "Non pertenzo a ningún partido político: é unha mala cousa que os tres de máis implantación en Galicia sexan unha verdadeira calamidade nacional, xa que están contribuíndo, e con eficacia, á destrucción do país. E non se decatan”. Para coñecer a súa traxectoria política e literaria resulta moi 
revelador ler a correspondencia con Ramón Piñeiro, que publicou no libro Cando o futuro comezaba. Correspondencia 1955-1990 (Galaxia, 2009).

Un último aspecto salientable é o da amizade. Franco Grande fomentou a amizade desde os anos de estudante e son numerosos os amigos que foi adquirindo ó longo da súa vida. De aí que en numerosos escritos fale deles. A principal mostra témola en A ilusión da esperanza. De Cabanillas a Baixeras (Edicións do Cumio, 1991), despois ampliado en A ilusión da esperanza. De Cabanillas a Xulio Ríos (Galaxia, 2019), con 49 retratos dalgúns dos seus moitos amigos que relatan a súa relación con eles, con anécdotas e vivencias experimentadas. Como el mesmo nos di, non están todos no libro, pero desexaba que todos se sentisen representados polos que incluíu nel. Alén deste libro, a moitos amigos dedicoulles diferentes artigos e homenaxes. En Compostela coñeceu a Ramón Lugrís e desde 1954 mantivo unha relación con este coñecido europeísta, a quen lembra en diversas ocasións (conversa con el en Grial 193, 2012, 63-75; Tempos novos 225, 2016, 60-61) e ó que, xuntamente con Xulio Ríos, lle preparou unha homenaxe no libro Ramón Lugrís. Sempre Galicia, sempre Europa (IGADI, 2015). Outro amigo con quen se relacionou moito na Coruña antes de que marchase para Londres foi Fernando Pérez-Barreiro Nolla e a el refírese en varias contribucións (nunha entrevista que lle fan el e Xulio Ríos en Grial 167, 2005, 112-123; no libro homenaxe O perdurable legado de Fernando Pérez-Barreiro Nolla, Edicións do Cumio, 2015, 15-17, ou no libro Homenaxe a Fernando Pérez-Barreiro Nolla editado como Cadernos Ramón Piñeiro XIX, 2011, 139-141).

A estes podemos sumar moitos máis, como Borobó (en Homenaxe a Borobó, Ediciós do Castro, 2003, 200-201 e en Anacos para Borobó, no 0, 2004, 9), Cunqueiro ("Expulsión e readmisión do periodista Alvaro Cunqueiro", A Trabe de ouro 4 (8), 1991, 105-114), Daniel Cortezón ("Unha amizade de máis de medio século”, no libro Daniel Cortezón, 2011, 129-133), Xaime Isla (en Homenaxe a Xaime Isla Couto, Galaxia, 1996, 120-126; Grial 207, 2015, 64-67), o padre Seixas ("Algunhas leccións do padre Seixas", en O padre Xaime Seixas Subirá. Pregoeiro da irmandade. Homenaxe no centenario do seu nacemento (1915-2015), Vigo, 2015, 69-70), Carlos Casares ("Altos e baixos na miña relación persoal con Carlos Casares", no libro Carlos Casares: homenaxe. De amicitia, Xunta de Galicia, Cadernos Ramón Piñeiro XXXVII, 2017, 197-200), Sebastián Martínez Risco (BRAG 378, 2017, 451-456), Xosé González Martínez ("Argallante maior do Reino de Breogán", no libro Xosé González Martínez. Mestre de vontade enerxética, 2017, 57), Manuel María (en Manuel María. Libro homenaxe organizado pola Asociación Cultural Xérmolos, Lugo, 2001, 653-654; Manuel María. Cecais hai unha luz. Memorabilia, Xunta de Galicia, Cadernos Ramón Piñeiro XXX, 2016), Xosé Ma Alvarez Blázquez (BRAG 361, 2000, 290, e en A palabra e os días. Homenaxe a Xosé M. $\stackrel{a}{ }$ 
Álvarez Blázquez, Galaxia, 2008, 83-91), Ernesto Guerra da Cal (Nós. Revista internacional galaicoportuguesa de cultura 13-18, 1989, 35-39, 499-500; A Trabe de ouro 2(26), 1996, 255-265; Ferrol Análisis, 17, 2002, 66-69), García Sabell ("A Humanidade do humanista", en Medicina e humanismo. Homenaxe a Domingo García-Sabell, Universidade de Santiago de Compostela e Galaxia, 2003, 49-57), Gonzalo R. Mourullo (en Homenaje al profesor Dr. Gonzalo Rodríguez Mourullo, Civitas, 2005, 37-49), Marina Mayoral (a quen lle respondeu ó seu discurso de ingreso na Academia o 2 de decembro de 2017) ou Luz Pozo Garza (Nordés 17-18, 1992, 115-117; Clave Orión IX-XI, 2002-2004, 135-138, e no libro Luz Pozo Garza. Ese xeito de amor que chamamos Galicia, 2019, 100).

Como non podía ser doutra maneira nesta nómina entran outros persoeiros que influíron na súa vida. Un deles é o mestre Otero Pedrayo, que figura nos Anos Escuros e tamén en "A galicidade da paisaxe en Otero Pedrayo" (en Homaxe a Ramón Otero Pedrayo no LXX aniversario do seu nacimento, Galaxia, 1958, 289-300) e "Otero Pedrayo en Compostela" (A Nosa Terra Extra, 8, 1987, 10-13). Outro é Piñeiro, a quen me referín xa e sobre o que podemos engadir aínda "Ramón Piñeiro e Manuel Murguía” (en Homenaxe a Ramón Piñeiro, Fundación Caixa Galicia, 1991, 225-231), "Arredor da mesa braseiro" (Grial 182, 2009, 116-119), "Europa dende Compostela" (no libro O europeísmo en Ramón Piñeiro, IGADI, 2009, 9-28), "Ramón Piñeiro e a política" (no libro Ramón Piñeiro. O amigo que lembramos, La Voz de Galicia, 2009, 55-58), "Primeiros anos de aprendizaxe (1954-60)" (no libro Homenaxe a Ramón Piñeiro, Xunta de Galicia, Centro Ramón Piñeiro para Investigación en Humanidades, 2009, 79-84). O terceiro é Francisco Fernández del Riego sobre o que escribiu o libro Francisco Fernández del Riego. Galeguista de acción e cultura (Ir Indo, 2000) e publicou diversos artigos, como "As teimas de don Paco" (en Homenaxe a Francisco Fernández del Riego, Galicia, 1975, 34-36), "iViva D. Paco!" (en Rolda de amigos derredor de Francisco Fernández del Riego. Galicia 1993, Ediciós do Castro, 1993, 81-83), un discurso (en Don Paco del Riego fillo adoptivo de Nigrán, Concello de Nigrán, 2002, 31-32), "Homo Faber" (en Homenaxe a Francisco Fernández del Riego, Fundación Premios da Crítica-Galicia, 2002, 117-119), "Presidente da Real Academia" (en Lume aceso. Francisco Fernández del Riego, Xunta de Galicia e Concello de Lourenzá, 2011, 127-128) ou en "Dende Policarpo Sanz, 24-1”" (no libro Francisco Fernández del Riego. Vigo dende o corazón de Galicia, Galaxia, 2013, 45-48). Sempre a amizade presente en Franco Grande e mesmo no último artigo que apareceu en La Voz de Galicia o 30 de marzo de 2020, un día antes de morrer escribiu: "Teño demostrado ter moitos amigos, de onte e de hoxe. E souben mantelos. Son moitos os amigos que me aturan e que eu aturei, cousa pouco común, e por tanto tempo...”. 
A toda esta produción hai que engadir as honras que recibiu. En 1978 foi nomeado académico de número da RAG, aínda que tardou moito en ler discurso, cousa que fixo en 1998 sobre O Antigo Réxime nunha familia do Baixo Miño, traballo no que nos deixou un estudo dos seus devanceiros e ó que lle contestou no nome da Academia Luz Pozo Garza (publicouse o libro en 2005). O 12 de novembro de 2009 recibiu na Estrada o Premio San Martiño de Normalización Lingüística. O 14 de xaneiro de 2012 celebrouse no Auditorio de Goián o acto do seu nomeamento como Fillo Predilecto de Tomiño (acordado polo Concello o 27 de outubro de 2011) e o 23 de xuño de 2012 recibiu a medalla de ouro da Irmandade Xurídica Galega, durante a asemblea celebrada na Coruña. Finalmente o 6 de xuño de 2016 a Fundación Lois Peña Novo fíxolle unha homenaxe en Redondela e colocou unha placa conmemorativa coa inscrición "Gratitude a Xosé L. Franco Grande, autor do dicionario galego en 1968, que nos fixo máis donos das palabras. Maio 2016".

Franco Grande, un home sabio, coherente, cunha coiraza exterior de seriedade que trataba de esconder a bondade do seu gran corazón; un home que amou a Galicia e a súa lingua, para quen Galicia sen galego non tiña razón de existir, o gran amigo dos amigos. Persoalmente a súa morte produciume un sentimento de desesperanza, pois foron 65 anos de irmandade e de ideoloxía compartida. Pero quédanos a lembranza, porque para min e para todos Xosé Luís seguirá sempre vivo.

\section{REFERENCIAS BIBLIOGRÁFICAS}

Fontoira Surís, Lydia (1973). O teatro en Illa Nova. Grial, 41, 360-369.

Lamas, J. (2016). Franco Grande reflexiona sobre o tempo no seu último poemario. La Voz de Galicia, 22/I/2016, 39.

López-Casanova, Arcadio (2016). A voz do mestre [Recención]. Grial 211, 91-92. Losada, X. R., (2016). Tempo e identidade [Recensión]. Tempos Novos, 225, 84. Pozo Garza, Luz (1988). X. L. Franco Grande: a búsqueda da identidade. Grial, 99, 37-42. 
Boletín da Real Academia Galega

Núm. 381, pp. 391-409

(C) 2020. Real Academia Galega

https://doi.org/10.32766/brag.381.802

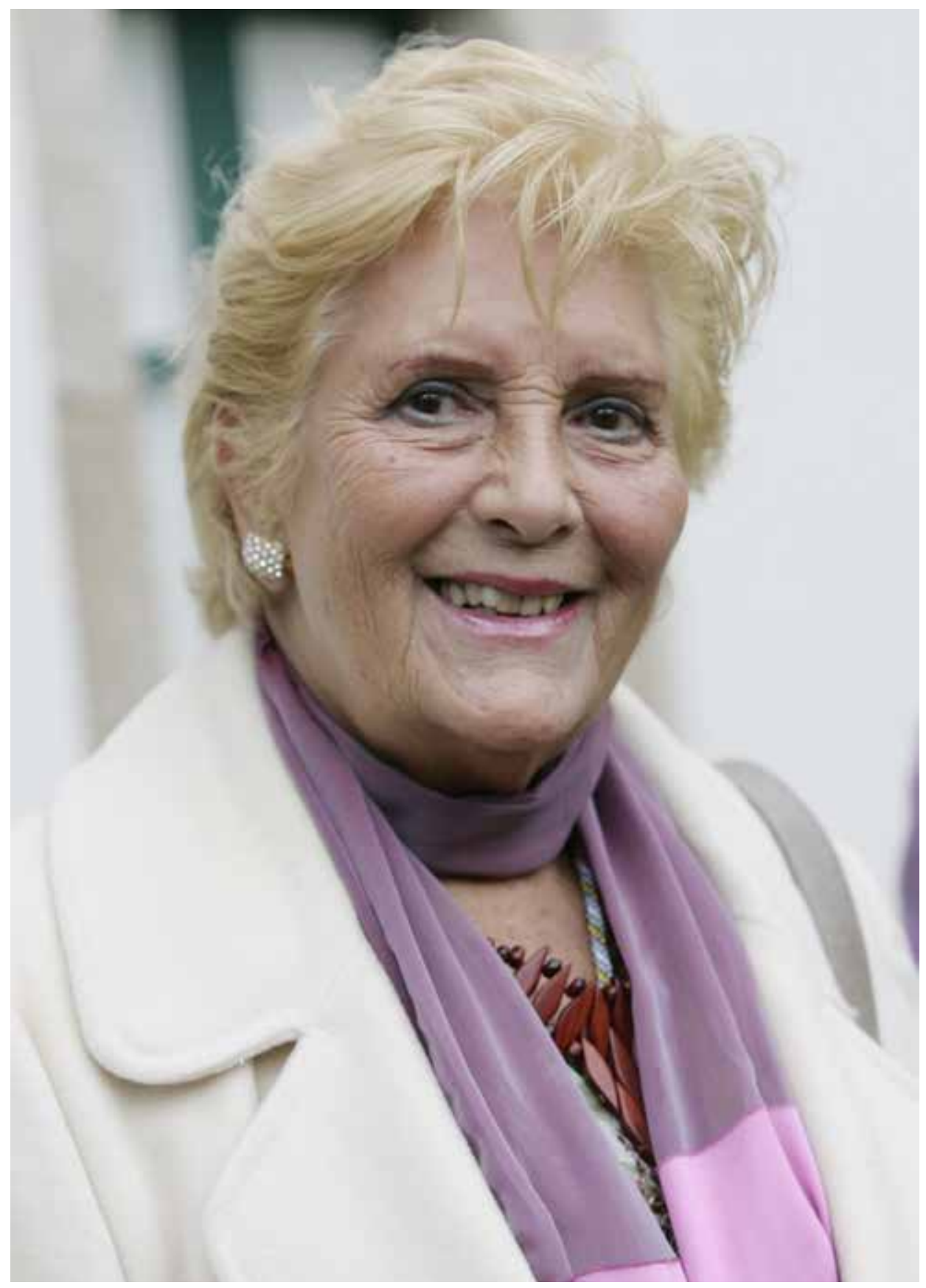

Luz Pozo Garza / Xosé Castro 


\title{
NO RELUMBRAR DA TÚA MEMORANZA
}

\author{
Salvador García-Bodaño
}

\author{
A Luz Pozo Garza \\ co meu fondo afecto
}

LUZ, intensa luz a nos alumear ben máis alá dos fins do noso tempo dende a lembranza das túas palabras, dende eses teus poemas refulxentes que nos chegan ca túa evocación e ca túa presenza xa imposíbel.

Véxote con aquel encanto aínda a rutilar en ti e a paixón que nos fuches doando nos teus versos. Naceras onde o mar de Ribadeo e onde o mar de A Coruña nos deixaches. No mar e no amor creaches o teu mundo.

No teu vivir nos deches en galego

o poema de "O paxaro na boca", e "As verbas derradeiras" e o "Concerto de outono", co "Códice Calixtino" e tamén co "Prometo a flor do loto". O teu ser nesta patria foi teu canto. 
Procúrote reter na acordanza

talmente como eras entre nós:

intelixente, sabia e máis creadora,

unha muller ideal e namorada

que vivirás por sempre nos teus libros,

extraordinaria luz das túas palabras.

Agora que os meus anos xa me achegan

cara ao fin do meu longo camiñar,

esváenseme recordos na memoria

e difusas vivencias xa perdidas, máis ti persistes Luz sen te apagar

cando unha vez máis leo os teus versos. 


\title{
LUZ P0ZO GARZA (1922-2020), AETERNITATE
}

\author{
Olivia Rodríguez González
}

Quen foi poeta, por riba de todo, ingresou na Real Academia Galega como membro de número o 29 de novembro de 1996. Era a segunda vez na historia da institución que unha muller ocupaba unha cadeira do pleno. Só a precedía a arquiveira Olga Gallego Domínguez, pois Francisca Herrera Garrido, electa en 1945, falecera antes da cerimonia de ingreso. Luz Pozo Garza era moi consciente de estar franqueando unhas portas que lentamente se irían abrindo a máis mulleres protagonistas da cultura galega. Un ano despois do ingreso como numeraria, e ata novembro de 2001, exercerá a vicesecretaría na directiva presidida por Francisco Fernández del Riego.

Levaba case cinco décadas como membro correspondente, cando Xesús Alonso Montero, Salvador García-Bodaño e Carlos Casares presentaron a proposta do seu ingreso como numeraria. No acto público pronuncia a poeta o discurso Diálogos con Rosalía ${ }^{1}$, mestura de poesía e ensaio en prosa rítmica, co que rende admiración agradecida a quen, xunto ao pobo, lle revelou "en toda a súa fermosura e paixón a verba primordial da nosa fala" (7).

Na resposta, salienta Xesús Alonso Montero que o tema rosaliano figuraba en discursos anteriores, pero non coa singularidade coa que o presenta Pozo Garza, xa que "se trata dunha interpretación de Rosalía feita, non desde as premisas discursivas do ensaio ou das técnicas da crítica, senón desde os enunciados da mesma poesía" (142). Deste xeito, Luz Pozo Garza proponse indagar nos enigmas de Rosalía de Castro, poñendo en paralelo o percorrido vital e creativo de ambas como mestra e discípula, nunha fusión de biografía real e voces poéticas: "conversamos dúas mulleres galegas nun diálogo, que é un acontecemento de libertade dos suxeitos" (35).

Así, tomando Rosalía como eixo, vai enfiando a poeta a súa autobiografía, desde que viu a luz na vila luguesa de Ribadeo o 21 de xullo de 1922. Dende moi cedo escoitaba os para ela misteriosos versos da padronesa nas veladas familiares: os pais recitaban trala cea, entre outros, poemas dela que deixaron pegada, leve

1 Indícanse a partir de agora entre parénteses os números de páxinas do discurso editado pola RAG. 
neses albores, pero marcadora do futuro dunha nena imaxinativa e vital: "E así quedei ferida" (45). A lembranza das lecturas a viva voz iría unida no futuro especialmente á nai, Luz Garza Feijoo, que a poeta representa nos seus versos en forma de fidalga orfa, tal como Rosalía de Castro. E, coma ela, necesitada de restitución simbólica a través do pazo da estirpe.

Luz Pozo Garza é arrincada do paso da nenez á adolescencia cando o golpe de estado de 1936 e a guerra subsecuente traen consigo, primeiro o encarceramento do pai, Gonzalo Pozo y Pozo (afiliado á Unión Republicana, procedente do Partido Republicano Radical Socialista) e logo a morte do irmán na fronte do Ebro. $\mathrm{O}$ primeiro é levado á cadea en Viveiro o 1 de agosto de 1936 e catro días despois, trasladado á de Lugo. Tras el vai a familia e instálase nunha pensión. En setembro é cesado no cargo de veterinario municipal de Viveiro, acusado de masón e membro da Fronte Popular. Finalmente é liberado grazas aos importantes contactos que ten no exército, onde exercera como veterinario militar antes do matrimonio. En 1938 marcha cos seus a vivir a Larache, ao abeiro dun seu primo, militar do Exército africanista no Protectorado español do Marrocos occidental. Alí chégalles a noticia de que o fillo, Gonzalo Pozo Garza, non sobrevive no hospital de Jaca ás feridas de morte do combate nas filas franquistas: "E era un soldado raso moi noviño / vencido do lado da victoria" (51).

África deixa na nena Luz - protexida en exceso, sen apenas pisar as rúas, indo da escola á casa e desta ás das distinguidas familias españolas da colonia militarunha impronta de beleza luminosa e paréntese temporal que levará consigo ao regreso en xuño de 1940 a Viveiro, unha vez restituído o pai no seu posto. É unha Luz anenada que continúa a xogar a facer versos como antes da guerra. Ten xa 18 anos. Completa os estudos na Academia Minerva en 1944 e acaba casando co director, o seu profesor de química Francisco Vázquez Ramudo. Imparte docencia alí, igual que a súa nai, mentres prepara o exame de mestra nacional. Nace en 1945 o primeiro fillo, chamado Gonzalo como o irmán prematuramente morto e como o pai, que falecerá en 1946. En 1953 matricúlase en Filoloxía Románica como alumna libre da Universidade de Oviedo. Así convértese en discípula de Emilio Alarcos Llorach, director anos despois da súa tese inconclusa sobre Luís Pimentel. O poeta fora veciño da pensión luguesa onde nai e fillos agardaban a liberación de Gonzalo Pozo, e tempo despois, Luz recordará a figura maltreita e desancorada do médico poeta que será un guieiro na súa escrita rosaliana cando se coñezan persoalmente en 1944.

Luz Pozo Garza fora nomeada en 1950 membro correspondente da RAG tras o éxito de crítica do seu primeiro poemario, Ánfora (1949), nado do presentimento de amor físico nunha relación epistolar e platónica desde 1946 con Eduardo Moreiras Collazo (1914-1991), tamén correspondente da RAG. O amigo 
non dubida en xestionar a edición en Vigo deste primeiro libro da autora, con cuberta deseñada por Xosé Sesto López. Ánfora resulta un poemario orixinal no panorama gris da posguerra e moi atrevido para unha autora da época, pois o tema amoroso desenvólvese con sensualidade e vitalismo, nuns escenarios de natureza entre salvaxe e simbólica. Foi decisiva para o recoñecemento da nova poeta a súa recepción no $\mathrm{ABC}$ polo pope da crítica Gerardo Diego. Ata entón, a sona da moza poeta, coñecida sobre todo a través das páxinas de Las Riberas del Eo desde 1945, non traspasara a contorna da mariña luguesa natal. Desde alí, o poeta e profesor Dionisio Gamallo Fierros actúa como o seu mentor e animador e é el quen fai chegar a Diego o poemario. A crítica establecía o parangón da poesía de Ánfora coa das hispanoamericanas J. Ibarbourou, G. Mistral e A. Storni. Pero non eran estas as lecturas frecuentadas daquela por Luz Pozo Garza. Si o era, en cambio, a obra de Vicente Aleixandre, cuxa Sombra del paraíso (1944) chega con forza a Ánfora. O poeta de Sevilla viña sendo mestre inspirador tamén para Eduardo Moreiras que, como Luz Pozo Garza, se entrega á poesía en galego desde 1955.

Ela faino antes, animada por Manuel María, cando en 1952 publica O paxaro na boca na colección Xistral que dirixe en Lugo Ángel Xohán. Deste xeito entra Luz Pozo Garza na literatura galega, formando parte, canda C. Kruckenberg, Tomás Barros, Manuel Cuña Novás e Antonio Tovar, da que X.L. Méndez Ferrín chamará, canonizándoa en 1990, "Promoción de enlace" entre a Xeración de 1936 e o primeiro grupo de poetas de posguerra. Este libriño comeza ademais a liña de depuración lírica que aínda está ausente nos poemarios casteláns escritos con anterioridade, e que no futuro reaparecerá mesmo en poemas con versículos nos que a melodía e o ritmo seguen a ser fundamentais. É unha época na que Luz Pozo Garza practica a autoedición e así aparecen dous novos libros de canto á vida fóra das convencións sociais e ao mar como espazo de liberdade: El vagabundo (1952), escrito en 1950 para concorrer ao Premio Adonais; e dez anos máis tarde, Cita en el viento (1962). A saída do prelo do segundo poemario ten lugar poucos meses despois do nacemento da terceira filla, Luz. En ambos os dous libros conta a autora con ilustradores que traballaban nese tempo na Coruña, Urbano Lugrís e José Ramón Villar Chao, fillo de Ramón Villar Ponte.

Con estes pintores relaciónase nas breves estadías na Coruña por mor da súa carreira de piano, pois obtén en 1949 o título superior no conservatorio da cidade. Acode co marido aos parladoiros de escritores do momento, entre eles, Miguel González Garcés e Manuel María, que viaxa desde as terras de Lugo. Colabora con Atlántida (1954-1956), dirixida de facto por Mariano Tudela e Urbano Lugrís; e con Vida Gallega, segunda época (1954-1963), impresa na Coruña con implicación maioritaria do grupo de Atlántida. Dará a coñecer a súa obra tamén en La Noche de Santiago de Compostela, Alba de Pontevedra e Vigo, Aturuxo de Ferrol, Alborada 
de Buenos Aires e Poesía Española e Ínsula de Madrid. E, como non, en Mensaxes de Poesía que en Vigo estrea en 1948 Eduardo Moreiras con poemas da autora.

A parella coñécese por fin en Baiona ese ano, acompañados de senllos cónxuxes. A partir de entón, farán todo o posible para encontrarse en segredo, viaxando Eduardo desde Vigo moitas veces en moto, e vivindo o amor nas montañas e bosques, como profetizara ela en Ánfora. Froito da paixón deses anos será a segunda filla de Luz, Mónica, nada en 1959. Os amantes continúan a comunicárense en cartas nas que ela leva o nome en clave de Ana e pide que el as destrúa despois de as ler.

En 1964, a familia múdase á Coruña, onde Francisco Vázquez exerce a docencia no ensino público. Luz Pozo Garza oposita en 1964 e traballa como profesora agregada de Instituto en Badajoz, Corcubión e por fin, na Coruña (primeiro no Instituto Salvador de Madariaga e despois, no Instituto Monelos).

En 1971 publica na revista Grial "Poema en cinco lembranzas para Rosalía". É o definitivo comezo do seu diálogo artístico coa poeta de Padrón. Ela sinala o precedente da branca sombra, ese mesmo ano, de Últimas palabras / Verbas derradeiras: "Eu vía a morte coma unha Sombra Branca, moi branca, mesmo transparente. Coma unha cousa amante que vive e non se ve" (31). Cando os namorados viaxan xuntos en moto, teñen un accidente nas inmediacións da Coruña, son ingresados no hospital e descubertos como amantes. Por iso os versos nacen da angustia ante a proximidade da morte física e a vivencia da ruptura co amado. Con limiar de Tomás Barros e ilustracións de Luís Seoane e Enrique Ferrer, é publicado en 1976 por Nordés, unha vez superada unha crise que tamén se agravara polo pasamento da nai en 1973. Por outra banda, a poeta xa atopara dez anos antes, se non comprensión, si aceptación por parte da parella lexítima nese tempo de castigo da muller adúltera fronte á patente de corso para os maridos infieis.

Luz Pozo Garza e Tomás Barros sacan do prelo entre 1975 e 1976 Nordés. Revista de creación e crítica, con funcións tamén de editora de poesía e ensaio. Ela é a directora real, pero figura oficialmente Barros como tal, por imposicións da administración franquista. O secretario é Isidro Conde e ilustra Luís Seoane. A segunda entrega da revista dedícase a Rosalía de Castro, con atención especial ao motivo da sombra: Luz Pozo fai en "La antítesis en la negra sombra" unha interpretación existencialista, no ronsel da de Ramón Piñeiro en 7 ensaios sobre Rosalía (1952).

Hai un cambio de rumbo no quefacer ensaístico, artístico e poético a partir da súa vida en parella, a partir de 1975, con Eduardo Moreiras, co que casa en 1982. Ambos viven na Coruña antes de instalarse en Vigo, onde Luz Pozo Garza exercerá a docencia no Instituto Santa Irene e, xa catedrática, no Instituto de Nigrán ata a xubilación en 1987. En 1981 publica en Ediciós do Castro, con limiar de Moreiras, Concerto de Outono, cun apartado rosaliano en varios tempos, que 
incorpora algúns dos poemas de 1971 e "busca a Rosalía como confidente nun diálogo antigo que non remata" (39).

Reinicia en 1985 Nordés, no prelo das Ediciós do Castro de Isaac Díaz Pardo, e con ilustracións propias -a pintura e o deseño son, como a música, artes que practica en paralelo á poesía-. Fóra da súa revista, publica en Grial de novo sobre a negra sombra rosaliana en 1987. E continúa os estudos críticos en libro, labor iniciado en 1952 con Álvaro Cunqueiro e Herba aquí ou acolá, que reedita en Galaxia en 1991. Prosegue con A bordo de "Barco sin luces" ou o mundo poético de Luis Pimentel, de 1990 (Sotelo Blanco, con edición revisada en Alvarellos, A bordo dun barco sen luces. O mundo poético de Luís Pimentel, 2011), Galicia ferida (a visión de Luís Seoane) (Ediciós do Castro,1994), Erotismo e conciencia mítica nas Cantigas de Amigo (1996) e, con H. Monteagudo e X. Alonso Montero, Tres poetas medievais da Ría de Vigo: Martín Codax, Mendiño e Johán de Cangas (Galaxia, 1998). Asemade elabora ensaios dunha autopoética de cerna simbolista, que se vai perfilando co tempo arredor da luz como principio xerador e a anulación do tempo na eternidade da beleza.

En 1986 edita o seu libro máis difundido, Códice Calixtino ( $1^{\mathbf{a}}$ ed., Sotelo Blanco) ao que pertence o poema "Falando a Rosalía", que abrirá o discurso na RAG de 1996. Pouco despois ten lugar a morte non agardada de Eduardo Moreiras, e durante o ano de dó, Luz escribe Prometo a flor de loto (Premio M. González Garcés, Deputación da Coruña, 1992), un pranto pola morte do amado que culmina coa esperanza do amor máis alá da desaparición física. O ciclo péchase con Vida secreta de Rosalía (Espiral Maior, 1996), poemario estreitamente relacionado co discurso de ingreso na RAG.

É o tempo de reabrir unha nova revista de creación e poesía, anunciada no número alfa de 1995 que pecha Nordés e que se dedica a Manoel Antonio. Do poeta mariñeiro nace o novo título da publicación, acollida polo Centro Ramón Piñeiro da Xunta de Galicia, Clave Orión (1995-2018).

No novo século, Luz Pozo Garza publica, instada por Andrés Pociña e Aurora López, un poema dramático que recrea o mito de Medea e que foi estreado na Coruña por Casa Hamlet. En Medea en Corinto (Linteo, 2002) xorde outravolta a a revivificación da propia Rosalía de Castro, "Que eu non son daquelas que cantan ás flores e ás pombas / Das que se resignan ante o desamor".

En 2004 prodúcese todo un acontecemento para Luz Pozo Garza: a publicación da súa obra ata entón completa, no selo Linteo de Ourense, co título Memoria solar. Edición ao coidado de Manuel Ramos, con rescate de poemas dispersos ou esquecidos, é revisada meticulosamente pola autora, que dá lecturas definitivas a todo o que leva publicado. $\mathrm{O}$ volume inclúe un novo poemario, As arpas de Iwerddon (edición exenta en Linteo, 2005), coas composicións de tema gaélico que foi 
adiantando noutras publicacións. Trátase dun canto á unión das culturas célticas do Atlántico, con presenza unha vez máis da saudade da camelia mística rosaliana e de Eduardo Moreiras no Alén. Ao amado dedica, a continuación, Vodas palatinas (ed. non venal, Espiral Maior/Ámbito Cultural C.I., 2005), de lembranzas do amor, reais e finxidas, en escenarios portugueses. Segue un poemario que recibe o prestixioso Premio da Crítica de poesía en lingua galega, con fermosos gravados de José Valentín acompañando cada un dos poemas: Deter o libro cunha flor (Baía Edicións, 2009).

De novo, un conmovedor e lúcido pranto revela o mellor da inspiración da poeta, golpeada pola morte da súa neta Natalia aos 39 anos, Sol de medianoche (Eurisaces, 2013). Son versos inspirados nas conversas coa rapaza, que a autora quere regalar en castelán á avoa santanderina. Luz Pozo Garza está atravesando a etapa de plenitude mística que caracteriza fortemente as dúas últimas producións. Rosa tántrica (Alvarellos, 2016) é unha homenaxe a Borges na que a poeta se involucra recreando textos do arxentino. Con Pazo de Tor (Alvarellos, 2018) pecha o círculo matricial Luz Garza / Rosalía de Castro, cunha ofrenda á estirpe da nai: o pazo que simbolicamente viña aparecendo desde os pasos de Rosalía en Arretén, ata a procura mística, en Deter o día cunha flor, dun paraíso onde mora xa a poeta eternamente.

Porque o 20 de abril de 2020 pechou os ollos Luz Pozo Garza con discreción e soidades de pandemia. Hoxe xace na cidade de acollida que tanto amou, a carón de súa nai Luz Garza Feijoo, no Cemiterio de Santo Amaro da Coruña, sen dúbida, un dos máis fermosos do mundo. 